\title{
Dicarbonyls and Advanced Glycation End-Products in the Development of Diabetic Complications and Targets for Intervention
}

\author{
Sebastian Brings ${ }^{1,2, *}$, Thomas Fleming ${ }^{1,3,4}$, Marc Freichel ${ }^{5}$, Martina U. Muckenthaler ${ }^{6}$, \\ Stephan Herzig ${ }^{4,7}$ and Peter P. Nawroth $1,3,4,7$ \\ 1 Department of Medicine I and Clinical Chemistry, University Hospital Heidelberg, 69120 Heidelberg, \\ Germany; thomas.fleming@med.uni-heidelberg.de (T.F.); peter.nawroth@med.uni-heidelberg.de (P.P.N.) \\ 2 \\ 3 German Center for Diabetes Research (DZD), 85764 Munich-Neuherberg, Germany \\ 4 Joint Heidelberg-IDC Translational Diabetes Program, Helmholtz Center, 85764 Munich-Neuherberg, \\ Germany; stephan.herzig@helmholtz-muenchen.de \\ 5 Institute of Pharmacology, University of Heidelberg, 69120 Heidelberg, Germany; \\ marc.freichel@pharma.uni-heidelberg.de \\ 6 Molecular Medicine Partnership Unit, University of Heidelberg, 69120 Heidelberg, Germany; \\ martina.muckenthaler@med.uni-heidelberg.de \\ 7 Institute for Diabetes and Cancer (IDC), Helmholtz Center, 85764 Munich-Neuherberg, Germany \\ * Correspondence: sebastian.brings@med.uni-heidelberg.de
}

Academic Editor: Casper G. Schalkwijk

Received: 25 January 2017; Accepted: 2 May 2017; Published: 5 May 2017

\begin{abstract}
Advanced glycation end-products (AGEs) are non-enzymatic protein and amino acid adducts as well as DNA adducts which form from dicarbonyls and glucose. AGE formation is enhanced in diabetes and is associated with the development of diabetic complications. In the current review, we discuss mechanisms that lead to enhanced AGE levels in the context of diabetes and diabetic complications. The methylglyoxal-detoxifying glyoxalase system as well as alternative pathways of AGE detoxification are summarized. Therapeutic approaches to interfere with different pathways of AGE formation are presented.
\end{abstract}

Keywords: advanced glycation end-products; diabetes; glyoxalase; aldose reductase; methylglyoxal; glyoxal; 3-deoxyglucosone

\section{Introduction}

Diabetes is characterized by elevated blood glucose levels and over 400 million people are suffering from diabetes worldwide [1]. Despite adjustment of blood glucose levels, diabetic complications develop frequently. These are a major cause of death, with estimated 4 million diabetes related deaths per year worldwide [1,2]. Glycation, the non-enzymatic post-translational modification of proteins is enhanced in diabetes and is associated with the development of diabetic complications [3,4]. In addition to proteins, the modification of DNA has also been described $[5,6]$. Advanced glycation end-products (AGEs) are the resulting modifications and form via a number of pathways $[7,8]$. The main precursors of AGEs are glucose and reactive dicarbonyls. Originally, AGE formation was discovered in the context of food preparation and these exogenous AGEs can contribute to the development of diabetes in addition to AGEs which originate in vivo [9-11]. The focus of the current review is on the in vivo formation and detoxification pathways of AGEs and their precursors in the context of diabetes. The importance of dicarbonyls and dicarbonyl-derived AGEs for the development of diabetic complications as well as potential therapeutic interventions are discussed. 


\section{Glucose and Dicarbonyl Dependent Advanced Glycation End-Product Formation}

The main pathways of AGE formation involve the reaction of glucose or dicarbonyls with primary amines ( $N$-terminal or lysine side chain) or the guanidine group of the arginine side chain (Figure 1 ). Other AGE precursors include polyunsaturated fatty acids as well as ascorbic acid [12,13].

According to the classical view of the Maillard reaction [11], glucose reacts with a primary amine which is followed by a series of rearrangements and/or fragmentation reactions [14-16] to yield the final AGEs; a process which takes days to weeks in a physiological setting $[17,18]$. $N^{\varepsilon}$-(carboxymethyl)-lysine (CML; see AGEs in Figure 2) was first detected in human urine in 1975 [19]. It was subsequently described as the first AGE by proving formation from the glucose-lysine adduct fructoselysine in 1986 [14]. Additional pathways which yield CML include the autoxidation of aldoses and ketoses [20], and the precursors ascorbic acid [12], polyunsaturated fatty acids [13] as well as the dicarbonyl pathway discussed in the following section. The main cross-linking AGE glucosepane forms via a glucose-lysine adduct which subsequently reacts with the guanidine side chain of arginine under physiological conditions [21,22].
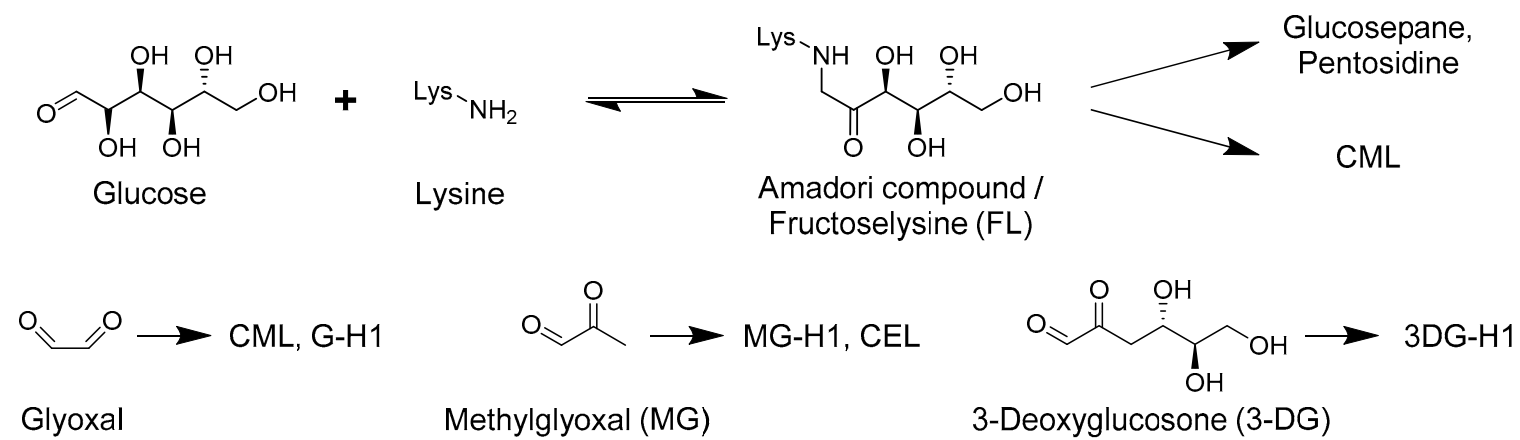

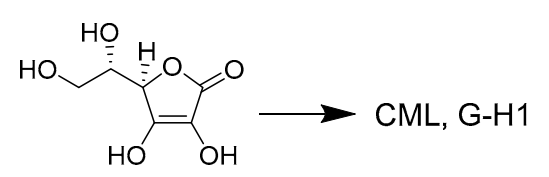

Ascorbic acid

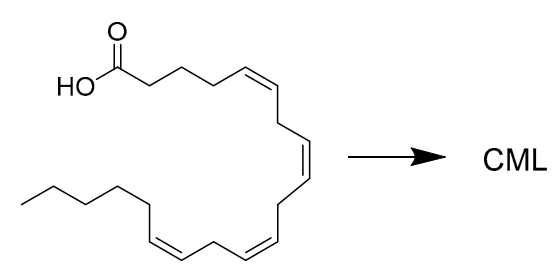

Arachidonic acid

Figure 1. Shown are the major precursors for the advanced glycation end-products (AGEs) identified in vivo. 3DG-H1: 3-Deoxyglucosone-hydroimidazolone 1; CML: $N^{\varepsilon}$-(carboxymethyl)-lysine; G-H1; Glyoxal-derived hydroimidazolone 1; MG-H1: Methyglyoxal-derived hydroimidazolone 1.

The other major glycation pathway, which is now also classified as part of the Maillard reaction [7], proceeds via the dicarbonyls methylglyoxal (MG), glyoxal and 3-deoxyclucosone (3-DG), of which MG is the most reactive compound [23]. Dicarbonyls form via several pathways some of which are intrinsically linked with the glucose derived pathway of AGE formation. Indeed, the glycolysis intermediates glyceraldehyde-3-phosphate and dihydroxyacetonephosphate are important precursors for MG [24]. Glucose-independent precursors of MG derive from the fatty acid and amino acid metabolism as well as from ascorbic acid $[25,26]$. Glyoxal formation proceeds via transition metal catalyzed fragmentation of glucose [27] and glucose amine adducts including fructoselysine (FL) $[15,16,28]$ as well as peroxidation of polyunsaturated fatty acids [29]. 3-DG forms from glucose adducts to $\mathrm{N}$-terminal amines or lysine side chains termed Amadori compound [30] as well as from fructose-3-phosphate [31]. Interestingly the latter compound forms after phosphorylation of the Amadori compound by fructosamine-3-kinase, in an enzymatic reaction termed deglycation [32].

The peroxidation of fatty acids can lead to the production of numerous dicarbonyls including malondialdehyde (MDA) and the aldehyde 4-hydroxynonenal (HNE) [8]. Relatively few studies have 
investigated changes of peroxidation specific precursors and subsequent amino acid modifications, termed advanced lipoxidation end-products (ALEs) in diabetes [33,34]. Furthermore, little is known about the relative abundance of ALEs compared to AGEs since only few comparative studies have been carried out. In one study, no MDA and HNE lysine adduct could be quantified by gas chromatography combined with mass spectrometry (GC-MS) while CML was quantified easily [35]. One issue with lipid peroxidation specific dicarbonyls and ALEs is their detection; mass spectrometry based methods as described in more detail in Section 5 for glucose dependent dicarbonyls and AGEs have been reported but they are labor intensive, involving immunopurification and other enrichment steps, which makes quantification difficult [36,37].

\section{Single AGEs}

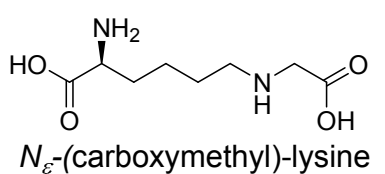

(CML)<smiles>CC(NCCCC[C@H](N)C(=O)O)C(=O)O[Mg]</smiles>

(CEL)<smiles>N[C@@H](CCCNC1=NC(=O)CN1)C(=O)O</smiles>

Glyoxal-derived hydroimidazolone 1 (G-H1)<smiles>CC1NC(NCCC[C@H](N)C(=O)O)=NC1=O</smiles>

Methylglyoxal-derived hydroimidazolone 1 (MG-H1)<smiles>NC(CCCNC1=NC(=O)C(CC(O)[C@H](O)CO)N1)C(=O)O</smiles>

3-Deoxyglucosone-derived hydroimidazolone 1 (3-DG-H1)

\section{Cross-linked AGEs}<smiles>N[C@@H](CCCCN1C[C@H](O)[C@@H](O)C[C@H]2N=C(NCCC[C@H](N)C(=O)O)N=C21)C(=O)O</smiles><smiles>NC(CCCC[n+]1cccc2nc(NCCC[C@H](N)C(=O)O)[nH]c21)C(=O)O</smiles>

Figure 2. The main AGEs that have been quantified in vivo are shown. AGE structures are given as AGE free adducts.

Dicarbonyls are more reactive than glucose making them relevant glycating agents despite the overall low dicarbonyl concentration found in tissue. The methylglyoxal-derived AGE, methylglyoxal-derived hydroimidazolone 1 (MG-H1) rapidly forms at the guanidine group of arginine [38]. In line with these findings, MG-H1 was reported as the most abundant AGE in numerous studies alongside the glucose-derived lysine arginine cross-link glucosepane (6-[2-\{[(4S)-4-ammonio-5-oxido-5-oxopentyl]amino\}-6,7-dihydroxy-6,7,8,8a-tetrahydroimidazo-[4,5b]-azepin-4(5H)-yl]-1-norleucinate) and CML [3,18,39,40]. Levels of the 3-DG derived arginine adduct 3-deoxyglucosone-derived-hydroimidazolone 1 (3-DG-H1) are also comparatively high but the compound has been quantified in fewer studies [39]. Additional abundant dicarbonyl derived AGEs are the MG-lysine adduct $N^{\varepsilon}$-(carboxyethyl)lysine (CEL) and glyoxal-derived hydroimidazolone (G-H1 also abbreviated Glarg) [3,39,41]. In addition to protein-AGE adducts, modification of DNA bases by MG has been reported [42]. The resulting products of deoxyguanosine modification are N2-(1-carboxyethyl)-2' deoxyguanosine (CEdG) and two structural isomers 3-(2'-deoxyribosyl)6,7-dihydro-6,7-dihydroxy-6/7-methylimidazo-[2,3-b]purine-9(8)one (MGdG) while deoxyadenosine modification results in N2-(1-carboxyethyl)-2'-deoxyadenosine (CEdA) [5,43]. Glyoxal modification of deoxyguanosine results in the adduct 3-(2'-deoxyribosyl)6,7-dihydro-6,7-dihydroxyimidazo-[2,3-b]purine-9(8)one (GdG) [5]. 
It is worth noting that, while formation of the major cross-link glucosepane starts with a glucose-lysine adduct, the pathway features an intermediate dicarbonyl structure [44]. The same is the case for pentosidine ((2S)-2-amino-6-[2-[[(4S)-4-amino-4-carboxybutyl] amino]imidazo[4,5-b]-pyridine-4-yl]hexanoic acid), a less abundant lysine-arginine cross-link [22]. Consequently, a large proportion of AGE intermediates, including the most abundant cross-link feature a dicarbonyl structure. Thus, glucose is an important precursor while the subsequent AGE formation frequently proceeds via free or protein bound dicarbonyl intermediates.

\section{Interpretation of Advanced Glycation End-Product Levels In Vivo}

The mechanism of AGE formation has been investigated in numerous in vitro studies and many different pathways have been discovered. For example CML can form via metal-catalyzed oxidative cleavage of the Amadori compound [14], polyunsaturated fatty acids [13] or ascorbic acid [12] as well as from glyoxal $[15,28]$ (Figure 1). The mechanism of AGE formation has been summarized in an extensive review recently [7]. In diabetes, elevated levels of AGEs have mostly been attributed to enhanced precursor levels such as glucose and dicarbonyls. In this section, we briefly summarize factors that affect AGE levels in vivo.

The amount of AGE protein adducts in vivo depends on the half-life of the protein, the rate of AGE formation and the chemical stability of the resulting AGE [45-47]. While AGEs overall are rather stable, there are differences: Both CML and CEL are recovered even after acid hydrolysis of proteins $[14,48]$. Glucosepane is stable for at least three weeks under physiologic conditions [22]. The half-life of MG-H1 was reported to be around 2-3 weeks under physiologic conditions [49,50].

The rate of AGE formation on each specific protein depends on the level of the precursor and the number of potential sites for modification. Only certain arginine and lysine residues of proteins are modified, supporting the notion that the primary and/or the secondary structure affect site reactivity. For example human serum albumin (HSA) contains 24 arginine residues, of which only five are modified with MG-H1 upon incubation with MG in vitro while one of these sites was particularly reactive [51]. A similar specificity is seen for the glycation of lysine residues of HSA [52]. However, considering the overall low amount of modified residues and the large number of reactive sites this is unlikely to be a limiting factor in vivo [39]. In addition to the precursor level, the formation of certain AGEs such as CML is catalyzed by transition metals which consequently can affect the rate of formation $[15,53,54]$.

CML was first identified on long lived proteins and a long protein half-life was deemed necessary for AGE-protein adducts in part due to the slow formation of AGEs via the Maillard reaction $[20,45,55]$. The great difference in reactivity at certain sites due to primary and secondary structure as well as the fast AGE formation pathway via reactive dicarbonyls explains why short-lived proteins are modified as well. It follows that a large amount of AGE-modified proteins are removed by proteolysis during normal turnover resulting in the release of non-protein bound AGEs, termed AGE free adducts.

An overview of the kinetics of AGE formation on proteins with a short and a long half-life is shown in Figure 3. Differences between normal and high precursor conditions, frequently encountered in diabetes are shown exemplary for one stable AGE (CML) and one labile AGE (MG-H1). Accumulation of stable AGEs over time occurs on long-lived proteins while modification of short-lived proteins results mainly in elevation of AGE free adducts $[47,56]$. Furthermore, labile AGEs such as MG-H1 should not accumulate significantly over time. This is supported by data from skin collagen which has a very long half-life where CML levels but not MG-H1 is strongly associated with donor age [56]. However, this is not true for all tissues as a strong correlation with age is seen for MG-H1 levels in lenses from normal donors $[7,40]$. This could be explained by a significant increase in the rate of precursor formation, namely MG, due to elevated production or an impaired detoxification mechanism. The study by Duran-Jimenez is also very interesting as it is one of the few where time dependent changes of different AGEs namely CML, MG-H1 and G-H1 as well as FL were investigated in a diabetic 
rat model [18]. While all compounds were elevated in diabetes, no time dependent increase was noted between 3 and 24 weeks of diabetes, possibly due to protein turnover.

A Normal precursor

$$
\begin{gathered}
\text { Glucose + Lys } \\
=\mathrm{CML} \\
\mathrm{MG}+\mathrm{Arg} \mathrm{O} \\
=\mathrm{MG}-\mathrm{H} 1 \mathrm{O} \\
\mathrm{i}=\mathrm{MG}-\mathrm{H} 1 \text { or } \\
\text { MG-H1 degradation product }
\end{gathered}
$$

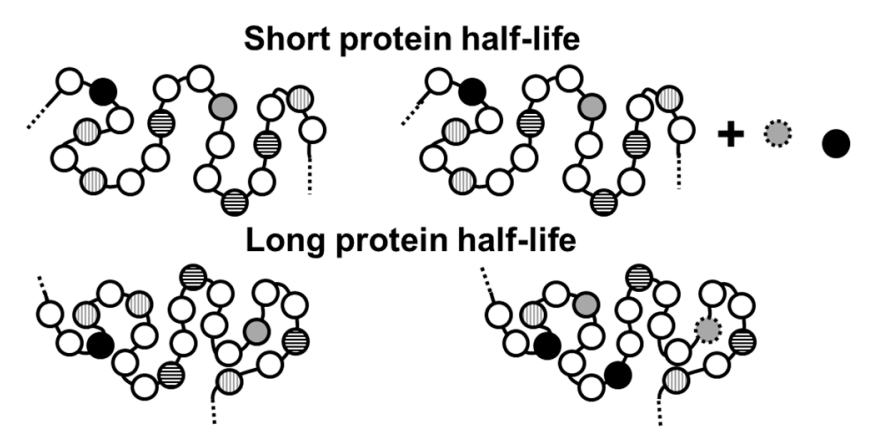

B Elevated precursor

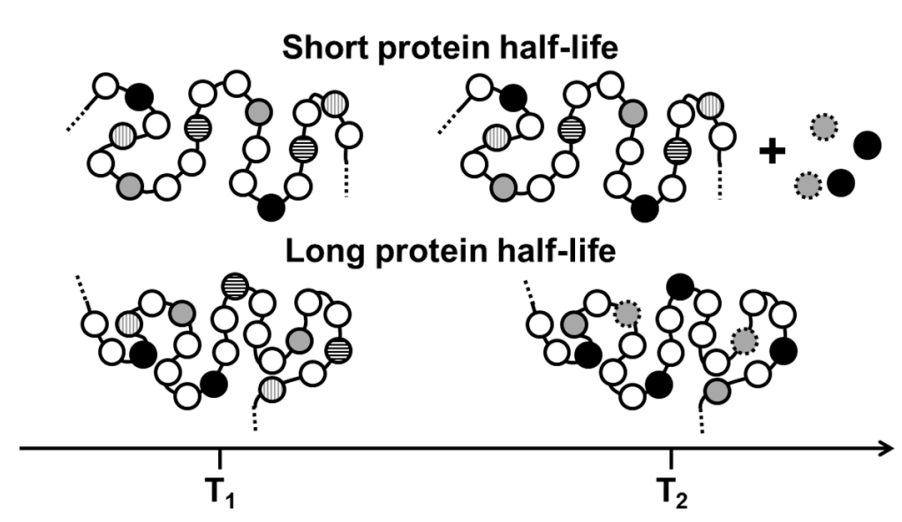

$$
\begin{gathered}
\text { Glucose } \uparrow+\text { Lys } \\
=\mathrm{CML} \uparrow \\
\text { MG } \uparrow+\operatorname{Arg} \bigcirc \\
=\mathrm{MG}-\mathrm{H} 1 \mathrm{O} \uparrow \\
=\mathrm{MG}-\mathrm{H} 1 \text { or }
\end{gathered}
$$

MG-H1 degradation product

Figure 3. Influence of protein half-life, chemical stability of AGEs and precursor level on the accumulation of AGE protein adducts over time. AGE formation under normal precursor conditions are shown in (A). Proteins with short half-life do not show long-term protein-AGE accumulation but AGE free adducts are released upon proteolysis. Stable AGEs such as CML accumulate over time on proteins with long half-life. The effect of an elevation of precursor levels as it is found in diabetes is shown in (B).

\section{Dicarbonyls in Diabetes and Relation to Diabetic Complications}

The reactive dicarbonyls MG [57-62], 3DG [58,59,62-64] and glyoxal [57,59,60,62] are elevated in serum of diabetic patients alongside blood glucose levels. Protein bound AGEs and AGE free adducts are increased in experimental models of diabetes $[18,39,65]$, and in diabetic patients in parallel with their precursors $[66,67]$. While glucose and intermediates of glucose metabolism are important dicarbonyl precursors, plasma levels of MG and glucose or glycated hemoglobin (HbA1c) levels do not necessarily correlate $[26,68,69]$. Reasons for the discrepancy between MG and blood glucose levels may be that additional MG precursor derive from the fatty acid and amino acid metabolism [26]. In addition changes in the enzymatic detoxification systems can contribute to altered dicarbonyl levels [70]. Consequently reducing the blood glucose level is likely to not be sufficient to correct the metabolic derangement and associated complications in diabetes. This is not to deny an essential role of glucose in the development of diabetic complications. This is supported by the findings that, in addition to $\mathrm{HbA1c}$, the glucose-lysine adduct FL as well as the glucose derived cross-link glucosepane are strong predictors of diabetic complications [3].

\subsection{Association of Methylglyoxal with Diabetic Complications}

The association between MG and MG-derived AGEs with diabetic complications has been investigated in numerous experimental and clinical studies. It was found that skin levels of AGEs are associated with the progression of diabetic nephropathy, diabetic neuropathy and diabetic retinopathy 
in type 1 diabetic humans [3]. Interestingly, in this study the correlation of MG-H1, with the development of diabetic neuropathy was very strong even when corrected for all other risk factors. This provides support for the finding that MG levels are particularly high in diabetic patients with enhanced pain sensitivity while MG was shown to be causative of hyperalgesia in mice [62]. In a separate study, MG-H1 plasma levels correlated with the heat pain detection threshold in the foot further confirming the importance of MG in diabetic neuropathy [71]. However, another recent study found no correlation between serum MG levels and peripheral neuropathy in type 2 diabetic patients [72]. As the authors commented this does not rule out a role for MG in the pathogenesis of diabetic neuropathy. Levels of the MG-derived AGE MG-H1 are extraordinarily high in the sciatic nerve so that MG plasma levels may not be a good predictor of MG levels in the nerve [73]. In addition, MG is notoriously difficult to quantify so that measurement of free and protein bound MG-H1 may be a better marker for MG exposure [74]. High MG levels are also associated with a faster rate of cognitive decline in humans as a possible mechanistic link between neurodegenerative disorders and diabetes [75].

MG has been implicated in the development of diabetic nephropathy in addition. A recent study in 1481 type 2 diabetic patients reported positive association of serum MG levels with albumin/creatinine ratio (ACR) at baseline while changes in the estimated glomerular filtration rate were inversely associated with MG during follow up [76]. Similarly levels of urinary and plasma MG levels correlated with basement membrane thickness in two cohorts of patients while MG levels in red blood cells were higher in progressors vs. non-progressors of diabetic nephropathy upon incubation with glucose [68]. This was confirmed by another study, which reported the correlation of plasma MG levels with serum creatinine and ACR in type 2 diabetic patients [77]. In addition plasma levels of the AGE MG-H1 and another MG derived AGE, CEL discriminated between fast and slow progressors with diabetic nephropathy in patients with type 1 diabetes [78]. The data is in contrast to the analysis of skin AGEs in type 1 diabetic patients mentioned previously [3]. While MG-H1 levels correlated strongly with neuropathy in the latter study, no correlation with nephropathy was seen. One major difference between the two studies is the analysis of skin tissue vs. plasma samples. Local exposure towards AGE precursors may well be different in those tissues. Furthermore, the most abundant proteins in plasma and skin are albumin and collagen respectively [79]. MG-H1 has a chemical half-life of 2-3 weeks [49,50] similar to albumin half-life of 19 days [80] as opposed to skin collagen which has a half-life of 15 years [47]. Thus, MG-H1 levels of albumin but not of collagen are affected by protein turnover.

MG levels are also positively related to intima media thickening and the elevation of blood pressure in diabetes supporting a link between MG and macroangiopathy [81]. The MG derived AGE, CEL also correlated with cardiovascular disease and all-cause mortality alongside the glucose derived AGEs pentosidine and CML [82]. This correlation was present even after correction for renal dysfunction, low-grade inflammation, endothelial dysfunction and arterial stiffness.

MG modified deoxyguanosine namely CEdG has also been detected in urine of healthy volunteers [6]. CEdG was subsequently shown to be elevated in urine but not in plasma of type 2 diabetic patients alongside another MG deoxyguanosine adduct, MGdG [5]. Levels of CEdG were also elevated in glomeruli of patients with diabetic kidney disease [83] and of diabetic rats [84]. The relevance of MG modified DNA bases in vivo is currently not known. Transformation of cells with CEdG modified vectors vs. unmodified vectors resulted in a significant reduction of protein activity [85]. However, as with AGE modified proteins, care needs to be taken when transferring results from in vitro experiments with strongly modified substrates to an in vivo setting $[86,87]$.

\subsection{Association of 3-Deoxyclucosone and Glyoxal with Diabetic Complications}

The majority of studies regarding dicarbonyls and dicarbonyl derived AGE formation have focused on MG. The other two dicarbonyls which have been investigated in the context of diabetes and AGE formation are 3-DG and glyoxal. Levels of the 3-DG derived AGE, 3-DG-H1, are present at similar 
levels as MG-H1 in human plasma and are elevated in experimental diabetes in the renal glomeruli the retina and the sciatic nerve [39]. Plasma levels of 3-DG also correlate with glomerular basement membrane thickness [68]. Interestingly, the correlation remained significant even after adjustment for $\mathrm{HbA1c}$ suggesting that factors in addition to glucose levels are responsible for 3-DG formation [68]. This is despite the fact that 3-DG forms mainly from glucose namely via the Amadori compound. One explanation for the discrepancy may be the activity of fructosamine-3-kinase which destabilizes glucose-amine adducts with resulting release of 3-DG [88]. Kusunoki et al. reported elevated serum levels of 3-DG in diabetic patients with normoalbuminuria and further elevations in those patients with microalbuminuria and overt proteinuria [63].

While levels of glyoxal $[57,59,62]$ are elevated in diabetes a relation to diabetic complications is currently uncertain. Compared to 3-DG and MG derived AGEs, the glyoxal-derived AGE G-H1 is present at rather low levels, except for plasma and elevations in diabetes are less pronounced [3,39,41]. In line with these findings no correlation of G-H1 skin levels with diabetic nephropathy, diabetic neuropathy and diabetic retinopathy were seen [3]. In contrast the glyoxal-derived DNA adduct GdG was strongly elevated in plasma of diabetic patients. It is thus possible that glyoxal is relevant for the glycation of DNA rather than protein.

\section{Quantification of Dicarbonyls and Advanced Glycation End-Products}

Liquid chromatography coupled tandem mass spectrometry (LC-MS/MS) employing internal, preferably isotopically labeled, standards is the method of choice for the quantification of dicarbonyls and several methods have been reported $[59,74,89,90]$. Alternatively, the use of GC-MS and high-performance liquid chromatography (HPLC) methods has been reported for the detection of MG [91,92]. Proper handling of samples and derivatization prior to analysis is essential due to the high reactivity of the compounds and the potential of MG formation from precursors glyceraldehyde-3-phosphate and dihydroxyacetonephosphate during sample processing [74]. The most commonly employed derivatizing agent is o-phenylenediamine but other reagents such as $O-(2,3,4,5,6$-pentafluorobenzyl)hydroxylamine hydrochloride or the fluorescent product 1,2-diamino-4,5-dimethoxybenzene have also been used successfully [74,92,93].

The large number of AGEs in combination with the differences in stability is a challenge for quantification. The method of choice for the measurement of AGE-protein adducts is LC-MS/MS analysis with stable isotopic dilution [94]. LC-MS/MS methods have also been published for the quantification of MG-DNA adducts $[43,95,96]$. For the absolute quantification of AGE protein adducts, proteins need to be hydrolyzed. Due to the instability of certain AGEs, enzymatic hydrolysis rather than acid hydrolysis is employed frequently and different digestion protocols have been developed $[40,97]$. Problems that can occur with the enzymatic approach are incomplete hydrolysis or bacterial contamination of the sample due to prolonged incubation at $37^{\circ} \mathrm{C}$. Bacterial contamination can be prevented by inclusion of antibiotics. Incomplete hydrolysis can be overcome by custom tailoring the digestion protocols for the specific protein of interest, for example the inclusion of collagenase for isolated collagen or collagen-rich tissue [94].

While mass spectrometry is considered the method of choice, it requires expensive equipment and the access to standards. Not all of the latter are commercially available and may require lengthy synthesis [98]. Alternatively AGEs can be detected by immunoassays. However, while numerous anti-AGE antibodies are commercially available, they are often not specific and can cross-react with other AGEs or the non-glycated protein. For example the "CML-specific" monoclonal antibody 6D12 reacts with CEL as well [99]. To exclude such cross-reactivity, blocking experiments should be carried out in order to determine specificity of the antibodies ideally using the AGE antigen in a sequence different from the one against which the antibody was raised [65].

The cross-linking AGE pentosidine was discovered and could be quantitated early due to chemical stability and the autofluorescent properties despite the low levels of this compound in tissues [46]. However, since most AGEs are not fluorescent this method is of limited use for AGE detection 
overall. A similar problem is encountered with the measurement of skin autofluorescence as an analytical tool for AGEs in patients. In support for skin autofluorescence it correlated with the AGEs pentosidine, $\mathrm{CML}$, CEL and mean $\mathrm{HbA1c}$ and was a strong predictor of cardiac mortality in diabetic patients $[100,101]$. The lack of fluorescence of major AGEs such as CML, glucosepane and MG-H1 as well as the interference with other fluorescent compounds such as nicotinamide adenine dinucleotide, flavine adenine dinucleotide and porphyrins are limitations of this method [97].

\section{Pathways of Dicarbonyl and Advanced Glycation End-Product Metabolism}

\subsection{The Glyoxalase System}

The glyoxalase system is the best characterized pathway for the metabolism of MG (Figure 4A) and has been covered in a recent review [102]. According to some estimates it metabolizes over $99 \%$ of the produced MG [103]. Additional dicarbonyls which are metabolized via this pathway are glyoxal, phenylglyoxal and hydroxypyruvaldehyde but not 3-DG [104-106]. Two enzymes, glyoxalase 1 (GLO1) and glyoxalase 2 (GLO2), make up the glyoxalase system in eukaryotes and require a catalytic amount of glutathione. First, reduced glutathione (GSH) reacts with the aldehyde of the dicarbonyl resulting in a hemithioacetal followed by the GLO1 catalyzed formation of S-D-lactoylglutathione in the case of MG. The second reaction is catalyzed by GLO2 and results in the production of D-lactate and reduced glutathione. GLO1 is the rate-limiting enzyme and is ubiquitously expressed at high levels $[107,108]$. The detoxification of glyoxal proceeds accordingly, albeit at a slower rate, and results in the formation of glycolate [106].

Alterations in the glyoxalase system may contribute to the development of diabetic complications. Reduction of GLO1 by small interfering RNA is associated with elevated MG-H1 protein adducts and changes indicative of diabetic nephropathy namely an increased mesangial area, a thickened glomerular basement membrane as well as albuminuria [109]. In the same study, overexpression of GLO1 protected from diabetic nephropathy [109]. Similar results were obtained in streptozotocin (STZ)-induced diabetic rats where albuminuria was lower in GLO1 overexpressing animals in parallel to decreased MG levels and MG-H1 levels [70]. Literature supports higher [110] or unaltered GLO1 activity [111] in red blood cells of type 1 and type 2 diabetic patients while patients with complications are reported to have higher levels than those without [110,111]. The presence of higher D-lactate levels alongside elevated GLO1 activity lends further support to the findings that GLO1 activity is elevated in diabetes [110]. Such an increase in the GLO1 system could be an adaptive response to deal with elevated MG levels [112]. These findings suggest that a lowered capacity of the GLO1 system is not causative of elevated MG levels in diabetes but rather that the system is overwhelmed by the amount of MG produced. However elevated levels of GLO1 in lenses of diabetic mice were paralleled by high MG levels suggesting that GLO1 activity may not be sufficient in diabetes [113]. Most studies regarding the glyoxalase system have focused on MG and its metabolites and relatively little is known about other glyoxalase metabolites such as the glyoxal derived glycolate. In a study already published in 1975 it was shown that glycolate levels are increased in urine of fed as well as fasted STZ-diabetic rats [114]. Authors did not detect concomitant changes of other metabolites related to glycolate metabolism such as glyoxylate so that the elevation may be indicative of enhanced glyoxal metabolism via the glyoxalase system in these animals. 
A<smiles></smiles>

B

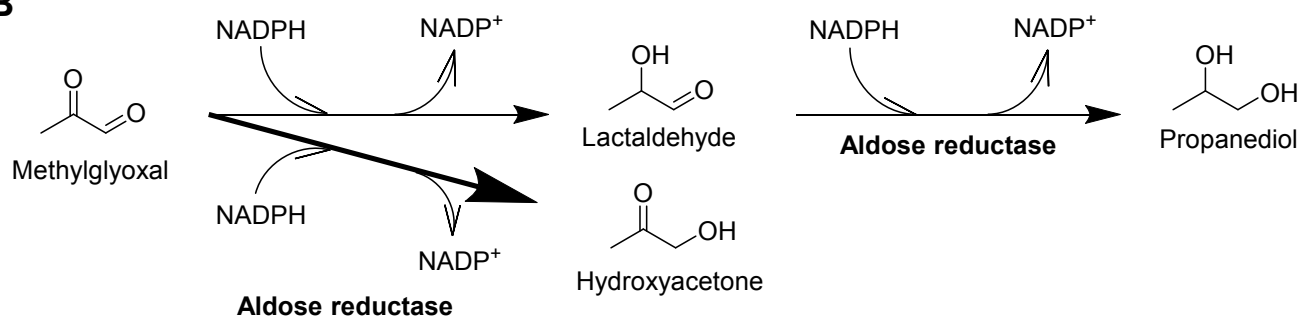

C

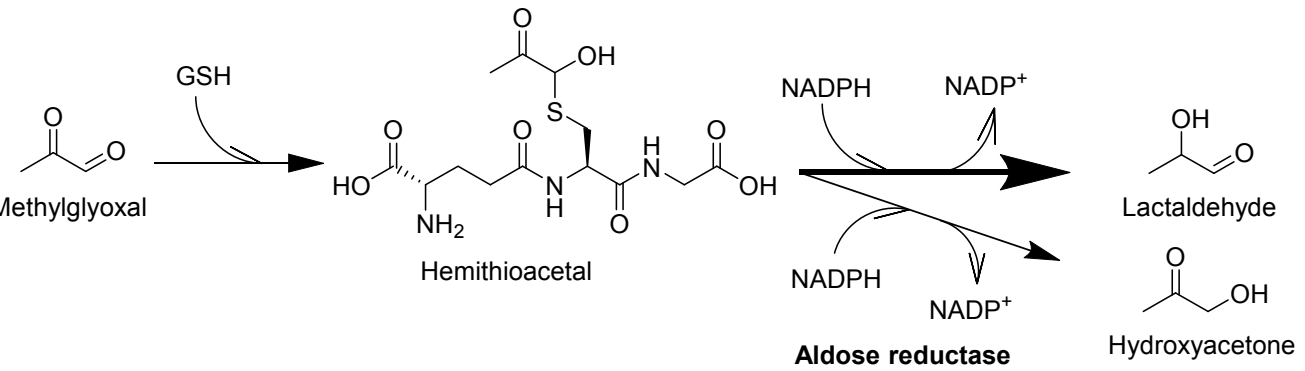

D<smiles>O=CC(=O)C[C@@H](O)[C@H](O)CO</smiles>

3-Deoxyglucosone (3-DG)

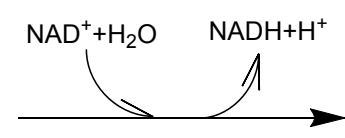

Aldehyde dehydrogenase<smiles>O=C(O)C(=O)C[C@@H](O)[C@H](O)CO</smiles>

2-Keto-3-deoxygluconic acid

Figure 4. Pathways of dicarbonyl detoxification. MG reacts with glutathione to yield hemithioacetal, the substrate for glyoxalase 1 (GLO1). (A) The product, S-D-lactoylglutathione, is hydrolyzed by glyoxalase 2 (GLO2) to yield D-lactate and reduced glutathione. Glyoxal is also metabolized via this pathway and results in glycolate production (not shown). Aldose reductases (B) catalyze the NADPH (nicotinamide adenine dinucleotide phosphate)-dependent reduction of MG which yield hydroxyacetone (major product) and lactaldehyde (minor product) in the absence of reduced glutathione (GSH). Lactaldehyde may be further reduced to propanediol. In the presence of GSH (C) aldose reductase acts on the hemithioacetal which results in a shift towards lactaldehyde production. Products of 3-DG and glyoxal metabolism of aldose reductase are 3-deoxyfructose and glycolaldehyde respectively (not shown). Aldehyde dehydrogenase (D) oxidizes dicarbonyls and is of potential importance for 3-DG metabolism with the resulting product being 2-keto-3-deoxygluconic acid. Products of MG and glyoxal oxidation are pyruvate and glyoxylate, respectively (not shown).

\subsection{Aldose Reductase}

Aldose reductases are another group of dicarbonyl metabolizing enzymes (Figure 4B,C). Products of NADPH (nicotinamide adenine dinucleotide phosphate)-dependent MG reduction are 
hydroxyacetone and lactaldehyde or propanediol in the case of two subsequent reductions [115]. In the absence of GSH, hydroxyacetone is the major product while lactaldehyde is the major product when GSH is present $[93,115]$. In addition to MG, aldose reductase converts glyoxal to glycolaldehyde [116] and 3-DG to 3-deoxyfructose [117].

Due to the high activity of the glyoxalase system it has been questioned whether aldose reductase is relevant for the detoxification of dicarbonyls in vivo. The effect of GSH levels on aldose reductase activity (AKR1B1) and GLO1 activity was investigated in this context in humans [115]. It was concluded that AKR1B1 assists GLO1 in the detoxification of MG in tissue where it is highly expressed and GSH levels are low. In an early study aldose reductase overexpression protected from MG as well as 3-DG-induced toxicity [118]. Another study reported a compensatory increase of aldose reductase activity (Akr1b3) in murine Schwann cells when GLO1 was knocked out [93]. These cells displayed MG levels and MG-H1 levels similar to wild type but were more sensitive towards external stimulation with MG compared to wild type cells. Moreover, the effect of aldose reductase knockout (AKR1B3) has been investigated in hearts of diabetic mice as well [119]. Mice not expressing the enzyme had higher levels of MG and glyoxal derived AGEs. Based on simulation experiments, the authors estimated that aldose reductase metabolizes $85 \%$ of glyoxal and $40 \%$ of MG at low dicarbonyl levels while the importance of GLO1 increases in the presence of high levels.

\subsection{Aldehyde Dehydrogenase}

The aldehyde dehydrogenase ALDH1A1 metabolizes MG by oxidation to pyruvate. However, the relative importance of this reaction in vivo is uncertain due to the presence of highly active GLO1 and AKR1B1 [120]. The importance for 3-DG metabolism is also in doubt since the major 3-DG metabolite in urine was identified to be 3-deoxyfructose, which is the product of aldose reductase [121]. Nevertheless, the 3-DG metabolite by ALDH1A1, 2-keto-3-deoxygluconic acid (Figure 4D), is increased in plasma and erythrocytes of diabetic patients [122]. In addition to erythrocytes, high activity levels of ALDH1A1 were found in lung, testis and liver [123]. ALDH1A1 is also capable of metabolizing glyoxal to glyoxylate but similar to 3-DG and MG the importance is uncertain [124]. Interestingly, ALDH1A1 also converts retinaldehyde to retinoic acid and knockdown of ALDH1A1 has been associated with browning of adipose tissue [125]. This effect was attributed to elevated levels of retinaldehyde.

\subsection{Fructosamine-3-kinase}

One of the major pathways of AGE formation is via glucose-amine-adducts which in the case of lysine results in FL formation. FL can rearrange or fragment to form stable AGEs including CML, glucosepane and pentosidine. Phosphorylation of FL by fructosamine-3-kinase (FN3K) results in the destabilization of FL and the release of free lysine thus reversing the glycation process [88]. A mouse deficient of FN3K displayed significantly elevated intracellular FL residues supporting the relevance of the mechanism in vivo [126]. Interestingly, deficiency of FN3K was not associated with a phenotype under normoglycemic conditions and data in a diabetic model of these mice are lacking. One possible explanation for the lack of a phenotype is that the dicarbonyl 3-DG forms in the course of the deglycation process catalyzed by FN3K [88]. Consequently, activity of FN3K is likely to result in a shift from glucose derived AGEs to dicarbonyl derived AGEs. Hence the enzyme could even exacerbate the glycative stress due to the higher reactivity of dicarbonyls.

\subsection{The Proteolytic System}

While stable AGEs accumulate over time on proteins with a long half-life such as collagen of the skin, the AGE burden in organs that have higher protein turnover is shifted to a certain extent away from the modified protein to the proteolysis machinery. In this regard proteolysis is the only universal AGE detoxification mechanism. AGE modified proteins are more resistant to digestion by the proteasomal — as well as the lysosomal proteolytic system [127]. This does not necessarily result in accumulation of AGE-modified proteins as long as the proteolytic system is able to adapt the 
digestive capacity. In support for such an adaptation in diabetes, a decrease in glomerular basement membrane digestibility was associated with elevated proteolytic activity of the glomeruli in diabetic rats [128,129]. A correlation between AGE-collagen adducts, collagen digestibility and the lysosomal protease cathepsin $\mathrm{L}$ was present in diabetic and healthy rats as further evidence of an adaptive increase of the proteolytic capacity [65]. The role of cathepsin D and L was investigated in vitro and both proteases were increased upon stimulation with AGE-modified albumin which resulted in a protective effect [130]. Additional support that the proteolytic system has to deal with a greater burden of AGEs in diabetes than is suggested by AGE-protein adducts comes from the elevation of AGE free adducts. The latter stem at least in part from the proteolysis of endogenously modified proteins and are increased to a far greater extent than the protein adducts in type 1 diabetic patients (10-fold vs. 3-fold elevation of free MG-H1 vs. MG-H1-protein adduct) [131]. The general increase of proteolysis in type 1 and type 2 diabetic patients is likely to contribute to such an elevation of AGE free adducts [132,133].

\section{Therapeutic Targeting of Dicarbonyls}

Based on the formation pathway for AGEs, elevated blood glucose and dicarbonyl levels can be targeted for treatment. However, since intensive lowering of blood glucose levels in diabetes is associated with an increase in total mortality options in this regard are limited [134]. In addition, there is evidence that MG levels are increased independent of blood glucose levels so that targeting the blood glucose level may not inhibit the elevated formation of AGEs via the dicarbonyl pathway [69]. Different approaches have been tested to reduce the dicarbonyl load and AGE formation independent of the lowering of blood glucose levels.

\subsection{Dicarbonyl Scavengers}

Scavengers were the first drugs to be developed and tested in clinical trials to target the elevated dicarbonyl levels and results have been reviewed in [135]. Aminoguanidine was the prototype AGE inhibitor [136]. It reacts rapidly with MG, glyoxal and 3-DG via its guanidine group and is capable of lowering MG levels in rats [23,137]. The scavenger prevented the development of albuminuria in two studies in rats but no effect on albuminuria was seen in another study [138-140]. Positive effects of aminoguanidine were also seen on diabetic retinopathy [141]. While preclinical studies were promising overall, clinical trials of the compound were disappointing. A trial in type 1 diabetic patients (A Clinical Trial In Overt Nephropathy of Type 1 Diabetics, ACTION I) failed to reach the primary endpoint (time to doubling of serum creatinine) but aminoguanidine treated patients displayed lower levels of proteinuria [142]. A subsequent trial in type 2 diabetic patients ( $A$ Clinical Trial In Overt Nephropathy of Type 2 Diabetics, ACTION II) had to be terminated early due to an unfavorable perceived risk-to-benefit ratio [143]. Side effects included glomerulonephritis associated with high levels of autoantibodies in patients receiving high doses of the drug $(2 \times 300 \mathrm{mg}$ per day) [142]. Additional issues with aminoguanidine are the rapid renal excretion as well as the induction of nitric oxide synthase $[23,144,145]$.

The B6 vitamer pyridoxamine scavenges dicarbonyls in vitro and consequently has also been tested as inhibitor of dicarbonyl derived AGE formation [146]. In addition, pyridoxamine acts as a metal chelator and could prevent AGE formation via inhibition of the transition metal catalyzed autoxidation of glucose or FL $[147,148]$. Treatment with pyridoxamine normalized albuminuria and lowered CML and CEL levels in a type 1 and type 2 diabetic rat model $[149,150]$. The investigational drug also inhibited the development of retinopathy paralleled by lower CML levels in STZ-induced diabetes in rats [151]. A phase 2 study analyzing the treatment effect of pyridoxamine on diabetic nephropathy reported a reduction in serum creatinine in CML and CEL [152] but a second larger scale trial did not find any significant effect on serum creatinine levels [153]. A recent phase 3 study (Clinical Trials.gov: NCT02156843) was terminated preliminarily. One issue with pyridoxamine may be the scavenging kinetics. Two molecules of pyridoxamine are needed to inactivate one molecule of the dicarbonyl MG and the reactivity is relatively low $[154,155]$. Should the scavenging activity be 
sufficient for MG binding in vivo another hurdle in diabetic patients would be competition for binding with metformin. The latter compound is the current first-line therapy for type 2 diabetes and reacts covalently with dicarbonyls at similar rate as pyridoxamine [156,157].

Metformin is the current treatment of choice for type 2 diabetes due to its glucose lowering effect [134]. MG lowering effects of metformin have been reported in addition [158]. The mechanism behind the decrease in MG levels by metformin is uncertain. Metformin reacts with MG via its guanidine group but the reaction proceeds slowly [159]. Nevertheless, a MG-metformin adduct has been detected in urine of patients treated with the drug at concentrations up to $4.3 \mu \mathrm{M}$ [156]. Lowering of MG levels by metformin is associated with an increase of GLO1 in peripheral blood mononuclear cells and a trend for increase in red blood cells [160]. Thus metformin may inhibit AGE formation directly through lowering of MG levels via two ways, namely MG scavenging and induction of GLO1 activity.

Alagebrium was designed as a compound to react with and break down existing AGEs rather than a scavenger of dicarbonyl compounds [161,162]. While alagebrium cleaves AGE cross-links in vitro there is evidence that the compound does not cleave cross-links in vivo [163]. Alternatively, alagebrium acts as a dicarbonyl scavenger and MG scavenging activity has been shown in rats and in vitro $[164,165]$. Positive effects were also seen on diabetic nephropathy in rats [166]. As opposed to pyridoxamine, clinical trials for alagebrium in diabetic and non-diabetic patients focused on macrovascular and cardiac related parameters such as blood pressure, left ventricular ejection fraction, left ventricular stiffness, endothelial function and arterial function [135]. While some clinical trials showed modest improvements, others were negative and currently no further trials are running.

\subsection{Alternative Advanced Glycation End-Product Lowering Strategies}

The induction of GLO1 is investigated as an alternative to scavengers to reduce dicarbonyl levels. GLO1 is regulated via binding of transcription factor Nrf2 to an antioxidant-response element (ARE) and as such activators of Nrf2 are capable of inducing GLO1 [167]. In a recent clinical trial of overweight and obese patients co-administration of the Nrf2 activators trans-resveratrol and hesperetin increased GLO1 activity in peripheral blood mononuclear cells [168]. This was associated with lower MG and fasting plasma glucose levels in a subgroup analysis of highly overweight patients (BMI $>27.5 \mathrm{~kg} / \mathrm{m}^{2}$ and $<30 \mathrm{~kg} / \mathrm{m}^{2}$ ).

Another approach to tackle elevated AGE formation in diabetes is transition metal chelation. The homeostasis of transition metals is disturbed in diabetes which can contribute to dicarbonyl and AGE formation via autoxidative pathways $[14,53,169,170]$. Chelator treatment lowers AGEs, normalizes collagen metabolism and slows down cataract formation in diabetic rats $[65,171]$. Improved cardiac function and sciatic nerve motor conduction velocity in diabetic rats has been demonstrated upon chelator treatment $[172,173]$. In support for an ameliorative effect in humans a recent clinical trial reported that EDTA treatment reduced the risk of adverse cardiovascular outcomes particularly in a subgroup analysis of diabetic patients although AGE levels were not measured [174,175]. In another phase 2 clinical trial, administration of the copper chelator trientine over one year partially restored left ventricular hypertrophy in diabetic patients [176].

\subsection{Future Perspectives for Therapeutic Advanced Glycation End-Product Targeting}

A large number of animal and clinical trials have been carried out with the aim to target the AGE pathway in diabetes. While animal trials often showed positive effects clinical trials were mostly negative and none of the compounds has been approved for treatment. Reasons may in part lie in the dosing and pharmacokinetics of administered drugs. In pre-clinical trials drugs were often given at high doses with aminoguanidine and pyridoxamine administered at up to $1 \mathrm{~g} / \mathrm{kg} /$ day in rats $[139,148$, 150]. Doses of pyridoxamine and aminoguanidine in clinical trials were much lower at $100-500 \mathrm{mg} /$ day $(1.4-7.1 \mathrm{mg} / \mathrm{kg} /$ day at $70 \mathrm{~kg}$ body weight) and 100-600 mg/day (1.4-8.6 mg/kg/day) respectively, even though allometric scaling needs to be considered [135,177]. It is thus possible that doses were too 
low to result in a therapeutic effect. Moreover, as mentioned by Borg and Forbes, it is possible that targeting one pathway of AGE formation is not enough [135]. Treatment with dicarbonyl scavengers and GLO1 inducers does not prevent the transition metal catalyzed fragmentation of glucose and glucose lysine adducts and formation of associated AGEs. Similarly chelator treatment does not target the formation of reactive dicarbonyls from triosephosphates [24]. Moreover, while the pathway for glucosepane formation features a dicarbonyl intermediate it is unknown whether scavenging compounds are capable of reacting with these in vivo thus lowering the amount of cross-links [44].

An important question for future treatment strategies to reduce AGEs regards the reversibility of existing AGEs. AGE breakers were designed based on the idea that a compound must cleave previously formed AGEs to treat complications associated with elevated AGE levels [135]. This is not necessarily the case, as AGE modified proteins are cleared via protein turnover. Thus, if the rate of AGE formation is lowered, the amount of AGE-protein adducts is decreased over time. In the kidney and the heart which are affected by diabetic complications, collagen has an average age of 80 and 40 days respectively so that even AGE-collagen adducts could theoretically be decreased, if the rate of formation of new adducts is lowered [178]. This should at least be the case for AGEs with a short chemical half-life such as MG-H1. When targeting enzymes associated with deglycation or dicarbonyl metabolism, care needs to be taken to avoid unwanted side effects. Up regulation of FN3K to lower the amount of glucose-lysine adducts may lead to an increased dicarbonyl stress through 3-DG production [179]. Similarly, inhibition of aldose reductase to lower sorbitol levels may lead to elevated levels of MG, glyoxal as well as 3-DG [93]. In summary, new treatment strategies to reduce the dicarbonyl load and associated complications in diabetes include GLO1 inducer and improved scavenger molecules. A complementary strategy to reduce the dicarbonyl load via the autoxidative fragmentation of glucose and fructoselysine is available by transition metal chelation.

\section{Summary and Conclusions}

The formation of dicarbonyls and resulting AGEs in diabetes are elevated and strongly associated with the development of complications. One reason for the therapeutic success of metformin may be that it interferes with dicarbonyl and AGE formation on several levels, namely by lowering blood glucose levels as well as the independent lowering of MG via scavenging and induction of glyoxalase 1. Consequently, future therapeutics for lowering dicarbonyls and AGE formation must be better at scavenging dicarbonyls or inducing GLO1 than metformin. Furthermore, alternative pathways for the reduction of AGE formation, such as transition metal chelation to reduce the autoxidative fragmentation of glucose could be targeted.

Acknowledgments: This work was supported by the Deutsche Forschungsgemeinschaft (DFG; SFB1118), the Dietmar Hopp Foundation (DHS) and the German Center for Diabetes Research (DZD).

Author Contributions: Sebastian Brings wrote the manuscript, Thomas Fleming, Marc Freichel, Martina Muckenthaler, Stephan Herzig and Peter P. Nawroth revised the manuscript.

Conflicts of Interest: Sebastian Brings, Thomas Fleming and Peter P. Nawroth are named as inventors in a pending patent that discloses the use of scavenger peptides for the treatment of MG induced complications. 


\section{Abbreviations}

$\begin{array}{ll}\text { ACR } & \text { Albumin/creatinine ratio } \\ \text { AGE } & \text { Advanced glycation end-product } \\ \text { CEdA } & \text { N2-(1-carboxyethyl)-2'-deoxyadenosine } \\ \text { CEdG } & \text { N2-(1-carboxyethyl)-2'deoxyguanosine } \\ \text { CEL } & N^{\varepsilon} \text {-(carboxyethyl)lysine } \\ \text { CML } & N^{\varepsilon} \text {-(carboxymethyl)-lysine } \\ \text { FL } & \text { Fructoselysine } \\ \text { FN3K } & \text { Fructoseamine-3-kinase } \\ \text { GdG } & \text { 3-(2'-Deoxyribosyl)-6,7-dihydro-6,7-dihydroxyimidazo-[2,3-b]purine-9(8)one } \\ \text { G-H1 } & \text { Glyoxal-derived hydroimidazolone 1 } \\ \text { Glucosepane } & \text { 6-[2-\{[(4S)-4-Ammonio-5-oxido-5-oxopentyl]amino\}-6,7-dihydroxy-6,7,8,8a-tetrahydroimidazo } \\ & {[4,5-b] \text {-azepin-4(5H)-yl]-l-norleucinate }} \\ \text { GLO1 } & \text { Glyoxalase 1 } \\ \text { GLO2 } & \text { Glyoxalase 2 } \\ \text { GSH } & \text { Glutathione } \\ \text { HSA } & \text { Human serum albumin } \\ \text { MG } & \text { Methylglyoxal } \\ \text { MG-H1 } & \text { Methylglyoxal-derived hydroimidazolone 1 } \\ \text { MGdG } & \text { 3-(2'-Deoxyribosyl)6,7-dihydro-6,7-dihydroxy-6/7-methylimidazo-[2,3- } b] \text { purine-9(8)one } \\ \text { Pentosidine } & \text { (2S)-2-Amino-6-[2-[[(4S)-4-amino-4-carboxybutyl]amino]imidazo[4,5- } b] \text { pyridin-4-yl]hexanoic } \\ & \text { acid } \\ \text { STZ } & \text { Streptozotocin } \\ \text { 3-DG } & \text { 3-Deoxyglucosone } \\ \text { 3-DG-H1 } & \text { 3-Deoxyglucosone-derived hydroimidazolone 1 } \\ & \end{array}$

\section{References}

1. International Diabetes Federation. IDF Diabetes Atlas, 7th ed.; International Diabetes Federation: Brussels, Belgium, 2015.

2. Forbes, J.M.; Cooper, M.E. Mechanisms of Diabetic Complications. Physiol. Rev. 2013, 93, 137-188. [CrossRef] [PubMed]

3. Genuth, S.; Sun, W.; Cleary, P.; Gao, X.; Sell, D.R.; Lachin, J.; Group, D.E.R.; Monnier, V.M. Skin Advanced Glycation End Products Glucosepane and Methylglyoxal Hydroimidazolone Are Independently Associated with Long-Term Microvascular Complication Progression of Type 1 Diabetes. Diabetes 2015, 64, 266-278. [CrossRef] [PubMed]

4. Genuth, S.; Sun, W.; Cleary, P.; Sell, D.R.; Dahms, W.; Malone, J.; Sivitz, W.; Monnier, V.M. Glycation and Carboxymethyllysine Levels in Skin Collagen Predict the Risk of Future 10-Year Progression of Diabetic Retinopathy and Nephropathy in the Diabetes Control and Complications Trial and Epidemiology of Diabetes Interventions and Complications Participants with Type 1 Diabetes. Diabetes 2005, 54, 3103-3111. [PubMed]

5. Waris, S.; Winklhofer-Roob, B.M.; Roob, J.M.; Fuchs, S.; Sourij, H.; Rabbani, N.; Thornalley, P.J. Increased DNA Dicarbonyl Glycation and Oxidation Markers in Patients with Type 2 Diabetes and Link to Diabetic Nephropathy. J. Diabetes Res. 2015, 2015, 915486. [CrossRef] [PubMed]

6. Schneider, M.; Thoss, G.; Hubner-Parajsz, C.; Kientsch-Engel, R.; Stahl, P.; Pischetsrieder, M. Determination of Glycated Nucleobases in Human Urine by a New Monoclonal Antibody Specific for N2-Carboxyethyl-2'-Deoxyguanosine. Chem. Res. Toxicol. 2004, 17, 1385-1390. [CrossRef] [PubMed]

7. Henning, C.; Glomb, M.A. Pathways of the Maillard Reaction Under Physiological Conditions. Glycoconj. J. 2016, 33, 499-512. [CrossRef] [PubMed]

8. Vistoli, G.; De Maddis, D.; Cipak, A.; Zarkovic, N.; Carini, M.; Aldini, G. Advanced Glycoxidation and Lipoxidation End Products (Ages and Ales): An Overview of Their Mechanisms of Formation. Free Radic. Res. 2013, 47 (Suppl. S1), 3-27. [CrossRef] [PubMed] 
9. Uribarri, J.; Cai, W.; Ramdas, M.; Goodman, S.; Pyzik, R.; Chen, X.; Zhu, L.; Striker, G.E.; Vlassara, H. Restriction of Advanced Glycation End Products Improves Insulin Resistance in Human Type 2 Diabetes: Potential Role of Ager1 and Sirt1. Diabetes Care 2011, 34, 1610-1616. [CrossRef] [PubMed]

10. Cai, W.; Ramdas, M.; Zhu, L.; Chen, X.; Striker, G.E.; Vlassara, H. Oral Advanced Glycation Endproducts (AGEs) Promote Insulin Resistance and Diabetes by Depleting the Antioxidant Defenses Age Receptor-1 and Sirtuin 1. Proc. Natl. Acad. Sci. USA 2012, 109, 15888-15893. [CrossRef] [PubMed]

11. Maillard, L.C. Action Des Acides Aminés Sur Les Sucres; Formation Des Mélanoïdines Par Voie Méthodique. C. R. Acad. Sci. 1912, 154, 66-68.

12. Dunn, J.A.; Ahmed, M.U.; Murtiashaw, M.H.; Richardson, J.M.; Walla, M.D.; Thorpe, S.R.; Baynes, J.W. Reaction of Ascorbate with Lysine and Protein Under Autoxidizing Conditions: Formation of $N^{\varepsilon}$-(Carboxymethyl)lysine by Reaction between Lysine and Products of Autoxidation of Ascorbate. Biochemistry 1990, 29, 10964-10970. [CrossRef] [PubMed]

13. Fu, M.X.; Requena, J.R.; Jenkins, A.J.; Lyons, T.J.; Baynes, J.W.; Thorpe, S.R. The Advanced Glycation End Product, $N^{\varepsilon}$-(Carboxymethyl)lysine, Is A Product of Both Lipid Peroxidation and Glycoxidation Reactions. J. Biol. Chem. 1996, 271, 9982-9986. [PubMed]

14. Ahmed, M.U.; Thorpe, S.R.; Baynes, J.W. Identification of N Epsilon-Carboxymethyllysine As A Degradation Product of Fructoselysine in Glycated Protein. J. Biol. Chem. 1986, 261, 4889-4894. [PubMed]

15. Hunt, J.V.; Bottoms, M.A.; Mitchinson, M.J. Oxidative Alterations in the Experimental Glycation Model of Diabetes Mellitus Are Due to Protein-Glucose Adduct Oxidation. Some Fundamental Differences in Proposed Mechanisms of Glucose Oxidation and Oxidant Production. Biochem. J. 1993, 291, 529-535. [CrossRef] [PubMed]

16. Hayashi, T.; Namiki, M. Formation of Two-Carbon Sugar Fragment At An Early Stage of the Browning Reaction of Sugar with Amine. Agric. Biol. Chem. 1980, 44, 2575-2580.

17. Valencia, J.V.; Weldon, S.C.; Quinn, D.; Kiers, G.H.; Degroot, J.; Tekoppele, J.M.; Hughes, T.E. Advanced Glycation End Product Ligands for the Receptor for Advanced Glycation End Products: Biochemical Characterization and Formation Kinetics. Anal. Biochem. 2004, 324, 68-78. [CrossRef] [PubMed]

18. Duran-Jimenez, B.; Dobler, D.; Moffatt, S.; Rabbani, N.; Streuli, C.H.; Thornalley, P.J.; Tomlinson, D.R.; Gardiner, N.J. Advanced Glycation End Products in Extracellular Matrix Proteins Contribute to the Failure of Sensory Nerve Regeneration in Diabetes. Diabetes 2009, 58, 2893-2903. [CrossRef] [PubMed]

19. Wadman, S.K.; De Bree, P.K.; Van Sprang, F.J.; Kamerling, J.P.; Haverkamp, J.; Vliegenthart, J.F.G. $\mathrm{N}^{\varepsilon}$-(Carboxymethyl)Lysine, A Constituent of Human Urine. Clin. Chim. Acta 1975, 59, 313-320. [CrossRef]

20. Thorpe, S.R.; Baynes, J.W. Cml: A Brief History. Int. Congr. Ser. 2002, 1245, 91-99. [CrossRef]

21. Biemel, K.M.; Reihl, O.; Conrad, J.; Lederer, M.O. Formation Pathways for Lysine-Arginine Cross-Links Derived From Hexoses and Pentoses by Maillard Processes: Unraveling the Structure of A Pentosidine Precursor. J. Biol. Chem. 2001, 276, 23405-23412. [CrossRef] [PubMed]

22. Biemel, K.M.; Friedl, D.A.; Lederer, M.O. Identification and Quantification of Major Maillard Cross-Links in Human Serum Albumin and Lens Protein. Evidence for Glucosepane As the Dominant Compound. J. Biol. Chem. 2002, 277, 24907-24915. [CrossRef] [PubMed]

23. Thornalley, P.J.; Yurek-George, A.; Argirov, O.K. Kinetics and Mechanism of the Reaction of Aminoguanidine with the $\alpha$-Oxoaldehydes Glyoxal, Methylglyoxal, and 3-Deoxyglucosone Under Physiological Conditions. Biochem. Pharmacol. 2000, 60, 55-65. [CrossRef]

24. Phillips, S.A.; Thornalley, P.J. The Formation of Methylglyoxal From Triose Phosphates. Investigation Using A Specific Assay for Methylglyoxal. Eur. J. Biochem. 1993, 212, 101-105. [CrossRef] [PubMed]

25. Smuda, M.; Glomb, M.A. Maillard Degradation Pathways of Vitamin C. Angew. Chem. 2013, 52, $4887-4891$. [CrossRef] [PubMed]

26. Kalapos, M.P. Where Does Plasma Methylglyoxal Originate From? Diabetes Res. Clin. Pract. 2013, 99, $260-271$. [CrossRef] [PubMed]

27. Wells-Knecht, K.J.; Zyzak, D.V.; Litchfield, J.E.; Thorpe, S.R.; Baynes, J.W. Mechanism of Autoxidative Glycosylation: Identification of Glyoxal and Arabinose As Intermediates in the Autoxidative Modification of Proteins by Glucose. Biochemistry 1995, 34, 3702-3709. [CrossRef] [PubMed]

28. Glomb, M.A.; Monnier, V.M. Mechanism of Protein Modification by Glyoxal and Glycolaldehyde, Reactive Intermediates of the Maillard Reaction. J. Biol. Chem. 1995, 270, 10017-10026. [PubMed] 
29. Mlakar, A.; Spiteller, G. Previously Unknown Aldehydic Lipid Peroxidation Compounds of Arachidonic Acid. Chem. Phys. Lipids 1996, 79, 47-53. [CrossRef]

30. Zyzak, D.V.; Richardson, J.M.; Thorpe, S.R.; Baynes, J.W. Formation of Reactive Intermediates From Amadori Compounds Under Physiological Conditions. Arch. Biochem. Biophys. 1995, 316, 547-554. [CrossRef] [PubMed]

31. Szwergold, B.S.; Kappler, F.; Brown, T.R. Identification of Fructose 3-Phosphate in the Lens of Diabetic Rats. Science 1990, 247, 451-454. [CrossRef] [PubMed]

32. Delpierre, G.; Van Schaftingen, E. Fructosamine 3-Kinase, An Enzyme Involved in Protein Deglycation. Biochem. Soc. Trans. 2003, 31, 1354-1357. [CrossRef] [PubMed]

33. Slatter, D.A.; Bolton, C.H.; Bailey, A.J. The Importance of Lipid-Derived Malondialdehyde in Diabetes Mellitus. Diabetologia 2000, 43, 550-557. [CrossRef] [PubMed]

34. Slatter, D.A.; Avery, N.C.; Bailey, A.J. Identification of A New Cross-Link and Unique Histidine Adduct From Bovine Serum Albumin Incubated with Malondialdehyde. J. Biol. Chem. 2004, 279, 61-69. [CrossRef] [PubMed]

35. Requena, J.R.; Fu, M.X.; Ahmed, M.U.; Jenkins, A.J.; Lyons, T.J.; Baynes, J.W.; Thorpe, S.R. Quantification of Malondialdehyde and 4-Hydroxynonenal Adducts to Lysine Residues in Native and Oxidized Human Low-Density Lipoprotein. Biochem. J. 1997, 322, 317-325. [CrossRef] [PubMed]

36. Weisser, J.; Ctortecka, C.; Busch, C.J.; Austin, S.R.; Nowikovsky, K.; Uchida, K.; Binder, C.J.; Bennett, K.L. A Comprehensive Analytical Strategy to Identify Malondialdehyde-Modified Proteins and Peptides. Anal. Chem. 2017, 89, 3847-3852. [CrossRef] [PubMed]

37. Ishii, T.; Kumazawa, S.; Sakurai, T.; Nakayama, T.; Uchida, K. Mass Spectroscopic Characterization of Protein Modification by Malondialdehyde. Chem. Res. Toxicol. 2006, 19, 122-129. [CrossRef] [PubMed]

38. Lo, T.W.; Westwood, M.E.; Mclellan, A.C.; Selwood, T.; Thornalley, P.J. Binding and Modification of Proteins by Methylglyoxal under Physiological Conditions. A Kinetic and Mechanistic Study with N $\alpha$-Acetylarginine,

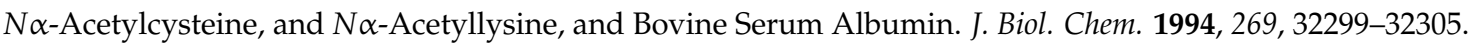
[PubMed]

39. Thornalley, P.J.; Battah, S.; Ahmed, N.; Karachalias, N.; Agalou, S.; Babaei-Jadidi, R.; Dawnay, A. Quantitative Screening of Advanced Glycation Endproducts in Cellular and Extracellular Proteins by Tandem Mass Spectrometry. Biochem. J. 2003, 375, 581-592. [CrossRef] [PubMed]

40. Smuda, M.; Henning, C.; Raghavan, C.T.; Johar, K.; Vasavada, A.R.; Nagaraj, R.H.; Glomb, M.A. Comprehensive Analysis of Maillard Protein Modifications in Human Lenses: Effect of Age and Cataract. Biochemistry 2015, 54, 2500-2507. [CrossRef] [PubMed]

41. Schmidt, R.; Bohme, D.; Singer, D.; Frolov, A. Specific Tandem Mass Spectrometric Detection of Age-Modified Arginine Residues in Peptides. J. Mass Spectrom. 2015, 50, 613-624. [CrossRef] [PubMed]

42. Pischetsrieder, M.; Seidel, W.; Münch, G.; Schinzel, R. N2-(1-Carboxyethyl)Deoxyguanosine, A Nonenzymatic Glycation Adduct of DNA, Induces Single-Strand Breaks and Increases Mutation Frequencies. Biochem. Biophys. Res. Commun. 1999, 264, 544-549. [CrossRef] [PubMed]

43. Frischmann, M.; Bidmon, C.; Angerer, J.; Pischetsrieder, M. Identification of DNA Adducts of Methylglyoxal. Chem. Res. Toxicol. 2005, 18, 1586-1592. [CrossRef] [PubMed]

44. Biemel, K.M.; Conrad, J.; Lederer, M.O. Unexpected Carbonyl Mobility in Aminoketoses: The Key to Major Maillard Crosslinks. Angew. Chem. 2002, 41, 801-804. [CrossRef]

45. Ahmed, N.; Thornalley, P.J. Advanced Glycation Endproducts: What Is Their Relevance to Diabetic Complications? Diabetes Obes. Metab. 2007, 9, 233-245. [CrossRef] [PubMed]

46. Sell, D.R.; Monnier, V.M. Structure Elucidation of A Senescence Cross-Link From Human Extracellular Matrix. Implication of Pentoses in the Aging Process. J. Biol. Chem. 1989, 264, 21597-21602. [PubMed]

47. Verzijl, N.; Degroot, J.; Thorpe, S.R.; Bank, R.A.; Shaw, J.N.; Lyons, T.J.; Bijlsma, J.W.; Lafeber, F.P.; Baynes, J.W.; Tekoppele, J.M. Effect of Collagen Turnover on the Accumulation of Advanced Glycation End Products. J. Biol. Chem. 2000, 275, 39027-39031. [CrossRef] [PubMed]

48. Teerlink, T.; Barto, R.; Ten Brink, H.J.; Schalkwijk, C.G. Measurement of $N^{\varepsilon}$-(Carboxymethyl)lysine and $N^{\varepsilon}$-(Carboxyethyl)lysine in Human Plasma Protein by Stable-Isotope-Dilution Tandem Mass Spectrometry. Clin. Chem. 2004, 50, 1222-1228. [CrossRef] [PubMed] 
49. Klopfer, A.; Spanneberg, R.; Glomb, M.A. Formation of Arginine Modifications in A Model System of $N^{\alpha}$-tert-Butoxycarbonyl (Boc)-Arginine with Methylglyoxal. J. Agric. Food Chem. 2011, 59, $394-401$. [CrossRef] [PubMed]

50. Ahmed, N.; Argirov, O.K.; Minhas, H.S.; Cordeiro, C.A.; Thornalley, P.J. Assay of Advanced Glycation Endproducts (Ages): Surveying Ages by Chromatographic Assay with Derivatization by 6-Aminoquinolyl-N-Hydroxysuccinimidyl-Carbamate and Application to $N^{\varepsilon}$-Carboxymethyl-Lysine- and $N^{\varepsilon}$-(1-Carboxyethyl)lysine-Modified Albumin. Biochem. J. 2002, 364, 1-14. [CrossRef] [PubMed]

51. Ahmed, N.; Thornalley, P.J. Peptide Mapping of Human Serum Albumin Modified Minimally by Methylglyoxal in Vitro and in Vivo. Ann. N. Y. Acad. Sci. 2005, 1043, 260-266. [CrossRef] [PubMed]

52. Iberg, N.; Fluckiger, R. Nonenzymatic Glycosylation of Albumin in Vivo. Identification of Multiple Glycosylated Sites. J. Biol. Chem. 1986, 261, 13542-13545. [PubMed]

53. Wolff, S.P.; Dean, R.T. Glucose Autoxidation and Protein Modification. The Potential Role of 'Autoxidative Glycosylation' in Diabetes. Biochem. J. 1987, 245, 243-250. [CrossRef] [PubMed]

54. Ahmed, M.U.; Dunn, J.A.; Walla, M.D.; Thorpe, S.R.; Baynes, J.W. Oxidative Degradation of Glucose Adducts to Protein. Formation of 3-( $N^{\varepsilon}$-Lysino)-Lactic Acid From Model Compounds and Glycated Proteins. J. Biol. Chem. 1988, 263, 8816-8821. [PubMed]

55. Dunn, J.A.; Mccance, D.R.; Thorpe, S.R.; Lyons, T.J.; Baynes, J.W. Age-Dependent Accumulation of $N \varepsilon$ -(Carboxymethyl)Lysine and $N^{\varepsilon}$-(Carboxymethyl)Hydroxylysine in Human Skin Collagen. Biochemistry 1991, 30, 1205-1210. [CrossRef] [PubMed]

56. Monnier, V.M.; Genuth, S.; Sell, D.R. The Pecking Order of Skin Advanced Glycation Endproducts (AGEs) As Long-Term Markers of Glycemic Damage and Risk Factors for Micro- and Subclinical Macrovascular Disease Progression in Type 1 Diabetes. Glycoconj. J. 2016, 33, 569-579. [CrossRef] [PubMed]

57. Lapolla, A.; Flamini, R.; Dalla Vedova, A.; Senesi, A.; Reitano, R.; Fedele, D.; Basso, E.; Seraglia, R.; Traldi, P. Glyoxal and Methylglyoxal Levels in Diabetic Patients: Quantitative Determination by A New GC/MS Method. Clin. Chem. Lab. Med. 2003, 41, 1166-1173. [CrossRef] [PubMed]

58. Odani, H.; Shinzato, T.; Matsumoto, Y.; Usami, J.; Maeda, K. Increase in Three $\alpha$, $\beta$-Dicarbonyl Compound Levels in Human Uremic Plasma: Specific in Vivo Determination of Intermediates in Advanced Maillard Reaction. Biochem. Biophys. Res. Commun. 1999, 256, 89-93. [CrossRef] [PubMed]

59. Scheijen, J.L.; Schalkwijk, C.G. Quantification of Glyoxal, Methylglyoxal and 3-Deoxyglucosone in Blood and Plasma by Ultra Performance Liquid Chromatography Tandem Mass Spectrometry: Evaluation of Blood Specimen. Clin. Chem. Lab. Med. 2014, 52, 85-91. [CrossRef] [PubMed]

60. Han, Y.; Randell, E.; Vasdev, S.; Gill, V.; Gadag, V.; Newhook, L.A.; Grant, M.; Hagerty, D. Plasma Methylglyoxal and Glyoxal Are Elevated and Related to Early Membrane Alteration in Young, Complication-Free Patients with Type 1 Diabetes. Mol. Cell. Biochem. 2007, 305, 123-131. [CrossRef] [PubMed]

61. Kong, X.; Ma, M.Z.; Huang, K.; Qin, L.; Zhang, H.M.; Yang, Z.; Li, X.Y.; Su, Q. Increased Plasma Levels of the Methylglyoxal in Patients with Newly Diagnosed Type 2 Diabetes 2. J. Diabetes 2014, 6, 535-540. [CrossRef] [PubMed]

62. Bierhaus, A.; Fleming, T.; Stoyanov, S.; Leffler, A.; Babes, A.; Neacsu, C.; Sauer, S.K.; Eberhardt, M.; Schnolzer, M.; Lasitschka, F.; et al. Methylglyoxal Modification of Nav1.8 Facilitates Nociceptive Neuron Firing and Causes Hyperalgesia in Diabetic Neuropathy. Nat. Med. 2012, 18, 926-933. [CrossRef] [PubMed]

63. Kusunoki, H.; Miyata, S.; Ohara, T.; Liu, B.F.; Uriuhara, A.; Kojima, H.; Suzuki, K.; Miyazaki, H.; Yamashita, Y.; Inaba, K.; et al. Relation Between Serum 3-Deoxyglucosone and Development of Diabetic Microangiopathy. Diabetes Care 2003, 26, 1889-1894. [CrossRef] [PubMed]

64. Wells-Knecht, K.J.; Lyons, T.J.; Mccance, D.R.; Thorpe, S.R.; Feather, M.S.; Baynes, J.W. 3-Deoxyfructose Concentrations Are Increased in Human Plasma and Urine in Diabetes. Diabetes 1994, 43, 1152-1156. [CrossRef] [PubMed]

65. Brings, S.; Zhang, S.; Choong, Y.S.; Hogl, S.; Middleditch, M.; Kamalov, M.; Brimble, M.A.; Gong, D.; Cooper, G.J. Diabetes-Induced Alterations in Tissue Collagen and Carboxymethyllysine in Rat Kidneys: Association with Increased Collagen-Degrading Proteinases and Amelioration by $\mathrm{Cu}(\mathrm{II})$-Selective Chelation. Biochim. Biophys. Acta 2015, 1852, 1610-1618. [CrossRef] [PubMed] 
66. Van Eupen, M.G.; Schram, M.T.; Colhoun, H.M.; Hanssen, N.M.; Niessen, H.W.; Tarnow, L.; Parving, H.H.; Rossing, P.; Stehouwer, C.D.; Schalkwijk, C.G. The Methylglyoxal-Derived AGE Tetrahydropyrimidine Is Increased in Plasma of Individuals with Type 1 Diabetes Mellitus and in Atherosclerotic Lesions and Is Associated with Svcam-1. Diabetologia 2013, 56, 1845-1855. [CrossRef] [PubMed]

67. Van Eupen, M.G.; Schram, M.T.; Colhoun, H.M.; Scheijen, J.L.; Stehouwer, C.D.; Schalkwijk, C.G. Plasma Levels of Advanced Glycation Endproducts Are Associated with Type 1 Diabetes and Coronary Artery Calcification. Cardiovasc. Diabetol. 2013, 12, 149. [CrossRef] [PubMed]

68. Beisswenger, P.J.; Drummond, K.S.; Nelson, R.G.; Howell, S.K.; Szwergold, B.S.; Mauer, M. Susceptibility to Diabetic Nephropathy Is Related to Dicarbonyl and Oxidative Stress. Diabetes 2005, 54, 3274-3281. [CrossRef] [PubMed]

69. Fleming, T.; Cuny, J.; Nawroth, G.; Djuric, Z.; Humpert, P.M.; Zeier, M.; Bierhaus, A.; Nawroth, P.P. Is Diabetes An Acquired Disorder of Reactive Glucose Metabolites and Their Intermediates? Diabetologia 2012, 55, 1151-1155. [CrossRef] [PubMed]

70. Brouwers, O.; Niessen, P.M.; Miyata, T.; Ostergaard, J.A.; Flyvbjerg, A.; Peutz-Kootstra, C.J.; Sieber, J.; Mundel, P.H.; Brownlee, M.; Janssen, B.J.; et al. Glyoxalase-1 Overexpression Reduces Endothelial Dysfunction and Attenuates Early Renal Impairment in A Rat Model of Diabetes. Diabetologia 2014, 57, 224-235. [CrossRef] [PubMed]

71. Sveen, K.A.; Karime, B.; Jorum, E.; Mellgren, S.I.; Fagerland, M.W.; Monnier, V.M.; Dahl-Jorgensen, K.; Hanssen, K.F. Small- and Large-Fiber Neuropathy After 40 Years of Type 1 Diabetes: Associations with Glycemic Control and Advanced Protein Glycation: The Oslo Study. Diabetes Care 2013, 36, 3712-3717. [CrossRef] [PubMed]

72. Hansen, C.S.; Jensen, T.M.; Jensen, J.S.; Nawroth, P.; Fleming, T.; Witte, D.R.; Lauritzen, T.; Sandbaek, A.; Charles, M.; Fleischer, J.; et al. The Role of Serum Methylglyoxal on Diabetic Peripheral and Cardiovascular Autonomic Neuropathy: The Addition Denmark Study. Diabet. Med. 2015, 32, 778-785. [CrossRef] [PubMed]

73. Karachalias, N.; Babaei-Jadidi, R.; Ahmed, N.; Thornalley, P.J. Accumulation of Fructosyl-Lysine and Advanced Glycation End Products in the Kidney, Retina and Peripheral Nerve of Streptozotocin-Induced Diabetic Rats. Biochem. Soc. Trans. 2003, 31, 1423-1425. [CrossRef] [PubMed]

74. Rabbani, N.; Thornalley, P.J. Measurement of Methylglyoxal by Stable Isotopic Dilution Analysis LC-MS/MS with Corroborative Prediction in Physiological Samples. Nat. Protoc. 2014, 9, 1969-1979. [CrossRef] [PubMed]

75. Beeri, M.S.; Moshier, E.; Schmeidler, J.; Godbold, J.; Uribarri, J.; Reddy, S.; Sano, M.; Grossman, H.T.; Cai, W.; Vlassara, H.; et al. Serum Concentration of An Inflammatory Glycotoxin, Methylglyoxal, Is Associated with Increased Cognitive Decline in Elderly Individuals. Mech. Ageing Dev. 2011, 132, 583-587. [CrossRef] [PubMed]

76. Jensen, T.M.; Vistisen, D.; Fleming, T.; Nawroth, P.P.; Rossing, P.; Jørgensen, M.E.; Lauritzen, T.; Sandbæk, A.; Witte, D.R. Methylglyoxal Is Associated with Changes in Kidney Function Among Individuals with Screen-Detected Type 2 Diabetes Mellitus. Diabet. Med. 2016, 33, 1625-1631. [CrossRef] [PubMed]

77. Lu, J.; Randell, E.; Han, Y.; Adeli, K.; Krahn, J.; Meng, Q.H. Increased Plasma Methylglyoxal Level, Inflammation, and Vascular Endothelial Dysfunction in Diabetic Nephropathy. Clin. Biochem. 2011, 44, 307-311. [CrossRef] [PubMed]

78. Beisswenger, P.J.; Howell, S.K.; Russell, G.B.; Miller, M.E.; Rich, S.S.; Mauer, M. Early Progression of Diabetic Nephropathy Correlates with Methylglyoxal-Derived Advanced Glycation End Products. Diabetes Care 2013, 36, 3234-3239. [CrossRef] [PubMed]

79. Neuman, R.E.; Logan, M.A. The Determination of Collagen and Elastin in Tissues. J. Biol. Chem. 1950, 186, 549-556. [PubMed]

80. Peters, T., Jr. Serum Albumin. In Advances in Protein Chemistry; Anfinsen, C.B.J.T.E., Frederic, M.R., Eds.; Academic Press: Cambridge, MA, USA, 1985; Volume 37, pp. 161-245.

81. Ogawa, S.; Nakayama, K.; Nakayama, M.; Mori, T.; Matsushima, M.; Okamura, M.; Senda, M.; Nako, K.; Miyata, T.; Ito, S. Methylglyoxal Is A Predictor in Type 2 Diabetic Patients of Intima-Media Thickening and Elevation of Blood Pressure. Hypertension 2010, 56, 471-476. [CrossRef] [PubMed] 
82. Nin, J.W.; Jorsal, A.; Ferreira, I.; Schalkwijk, C.G.; Prins, M.H.; Parving, H.H.; Tarnow, L.; Rossing, P.; Stehouwer, C.D. Higher Plasma Levels of Advanced Glycation End Products Are Associated with Incident Cardiovascular Disease and All-Cause Mortality in Type 1 Diabetes: A 12-Year Follow-Up Study. Diabetes Care 2011, 34, 442-447. [CrossRef] [PubMed]

83. Li, H.; Nakamura, S.; Miyazaki, S.; Morita, T.; Suzuki, M.; Pischetsrieder, M.; Niwa, T. N2-Carboxyethyl-2'-Deoxyguanosine, A DNA Glycation Marker, in Kidneys and Aortas of Diabetic and Uremic Patients. Kidney Int. 2006, 69, 388-392. [CrossRef] [PubMed]

84. Nakamura, S.; Li, H.; Adijiang, A.; Pischetsrieder, M.; Niwa, T. Pyridoxal Phosphate Prevents Progression of Diabetic Nephropathy. Nephrol. Dial. Transplant. 2007, 22, 2165-2174. [CrossRef] [PubMed]

85. Breyer, V.; Frischmann, M.; Bidmon, C.; Schemm, A.; Schiebel, K.; Pischetsrieder, M. Analysis and Biological Relevance of Advanced Glycation End-Products of DNA in Eukaryotic Cells. FEBS J. 2008, 275, 914-925. [CrossRef] [PubMed]

86. Heizmann, C.W. The Mechanism by Which Dietary AGEs Are A Risk to Human Health Is Via Their Interaction with RAGE: Arguing Against the Motion. Mol. Nutr. Food Res. 2007, 51, 1116-1119. [CrossRef] [PubMed]

87. Ramasamy, R.; Yan, S.F.; Schmidt, A.M. Arguing for the Motion: Yes, RAGE Is A Receptor for Advanced Glycation Endproducts. Mol. Nutr. Food Res. 2007, 51, 1111-1115. [CrossRef] [PubMed]

88. Szwergold, B.S.; Howell, S.; Beisswenger, P.J. Human Fructosamine-3-Kinase. Diabetes 2001, 50, $2139-2147$. [CrossRef] [PubMed]

89. Henning, C.; Liehr, K.; Girndt, M.; Ulrich, C.; Glomb, M.A. Extending the Spectrum of $\alpha$-Dicarbonyl Compounds in Vivo. J. Biol. Chem. 2014, 289, 28676-28688. [CrossRef] [PubMed]

90. Gensberger-Reigl, S.; Huppert, J.; Pischetsrieder, M. Quantification of Reactive Carbonyl Compounds in Icodextrin-Based Peritoneal Dialysis Fluids by Combined UHPLC-DAD and -MS/MS Detection. J. Pharm. Biomed. Anal. 2016, 118, 132-138. [CrossRef] [PubMed]

91. Degen, J.; Vogel, M.; Richter, D.; Hellwig, M.; Henle, T. Metabolic Transit of Dietary Methylglyoxal. J. Agric. Food Chem. 2013, 61, 10253-10260. [CrossRef] [PubMed]

92. Mclellan, A.C.; Phillips, S.A.; Thornalley, P.J. The Assay of Methylglyoxal in Biological Systems by Derivatization with 1,2-Diamino-4,5-Dimethoxybenzene. Anal. Biochem. 1992, 206, 17-23. [CrossRef]

93. Morgenstern, J.; Fleming, T.; Schumacher, D.; Eckstein, V.; Freichel, M.; Herzig, S.; Nawroth, P. Loss of Glyoxalase 1 Induces Compensatory Mechanism to Achieve Dicarbonyl Detoxification in Mammalian Schwann Cells. J. Biol. Chem. 2017, 292, 3224-3238. [CrossRef] [PubMed]

94. Rabbani, N.; Ashour, A.; Thornalley, P.J. Mass Spectrometric Determination of Early and Advanced Glycation in Biology. Glycoconj. J. 2016, 33, 553-568. [CrossRef] [PubMed]

95. Thornalley, P.J.; Waris, S.; Fleming, T.; Santarius, T.; Larkin, S.J.; Winklhofer-Roob, B.M.; Stratton, M.R.; Rabbani, N. Imidazopurinones Are Markers of Physiological Genomic Damage Linked to DNA Instability and Glyoxalase 1-Associated Tumour Multidrug Resistance. Nucleic Acids Res. 2010, 38, 5432-5442. [CrossRef] [PubMed]

96. Synold, T.; Xi, B.; Wuenschell, G.E.; Tamae, D.; Figarola, J.L.; Rahbar, S.; Termini, J. Advanced Glycation End Products of DNA: Quantification of N2-(1-Carboxyethyl)-2'-Deoxyguanosine in Biological Samples by Liquid Chromatography Electrospray Ionization Tandem Mass Spectrometry. Chem. Res. Toxicol. 2008, 21, 2148-2155. [CrossRef] [PubMed]

97. Thornalley, P.J.; Rabbani, N. Detection of Oxidized and Glycated Proteins in Clinical Samples Using Mass Spectrometry-A User's Perspective. Biochim. Biophys. Acta 2014, 1840, 818-829. [CrossRef] [PubMed]

98. Draghici, C.; Wang, T.; Spiegel, D.A. Concise Total Synthesis of Glucosepane. Science 2015, 350, $294-298$. [CrossRef] [PubMed]

99. Koito, W.; Araki, T.; Horiuchi, S.; Nagai, R. Conventional Antibody Against Ne-(Carboxymethyl)Lysine (CML) Shows Cross-Reaction to Ne-(Carboxyethyl)Lysine (CEL): Immunochemical Quantification of CML with A Specific Antibody. J. Biochem. 2004, 136, 831-837. [CrossRef] [PubMed]

100. Meerwaldt, R.; Graaff, R.; Oomen, P.H.; Links, T.P.; Jager, J.J.; Alderson, N.L.; Thorpe, S.R.; Baynes, J.W.; Gans, R.O.; Smit, A.J. Simple Non-Invasive Assessment of Advanced Glycation Endproduct Accumulation. Diabetologia 2004, 47, 1324-1330. [CrossRef] [PubMed]

101. Meerwaldt, R.; Lutgers, H.L.; Links, T.P.; Graaff, R.; Baynes, J.W.; Gans, R.O.; Smit, A.J. Skin Autofluorescence Is A Strong Predictor of Cardiac Mortality in Diabetes. Diabetes Care 2007, 30, 107-112. [CrossRef] [PubMed] 
102. Sousa Silva, M.; Gomes, R.A.; Ferreira, A.E.; Ponces Freire, A.; Cordeiro, C. The Glyoxalase Pathway: The First Hundred Years... and Beyond. Biochem. J. 2013, 453, 1-15. [CrossRef] [PubMed]

103. Rabbani, N.; Thornalley, P.J. Dicarbonyl Proteome and Genome Damage in Metabolic and Vascular Disease. Biochem. Soc. Trans. 2014, 42, 425-432. [CrossRef] [PubMed]

104. Vander Jagt, D.L.; Han, L.P.; Lehman, C.H. Kinetic Evaluation of Substrate Specificity in the Glyoxalase-I-Catalyzed Disproportionation of -Ketoaldehydes. Biochemistry 1972, 11, 3735-3740. [CrossRef] [PubMed]

105. Vander Jagt, D.L.; Daub, E.; Krohn, J.A.; Han, L.P. Effects of $\mathrm{pH}$ and Thiols on the Kinetics of Yeast Glyoxalase I. An Evaluation of the Random Pathway Mechanism. Biochemistry 1975, 14, 3669-3675. [CrossRef] [PubMed]

106. Clelland, J.D.; Thornalley, P.J. S-2-Hydroxyacylglutathione-Derivatives: Enzymatic Preparation, Purification and Characterisation. J. Chem. Soc. Perkin Trans. 1 1991, 3009-3015. [CrossRef]

107. Thornalley, P.J. Glyoxalase I-Structure, Function and A Critical Role in the Enzymatic Defence against Glycation. Biochem. Soc. Trans. 2003, 31, 1343-1348. [CrossRef] [PubMed]

108. Rabbani, N.; Xue, M.; Thornalley, P.J. Dicarbonyls and Glyoxalase in Disease Mechanisms and Clinical Therapeutics. Glycoconj. J. 2016, 33, 513-525. [CrossRef] [PubMed]

109. Giacco, F.; Du, X.; D'agati, V.D.; Milne, R.; Sui, G.; Geoffrion, M.; Brownlee, M. Knockdown of Glyoxalase 1 Mimics Diabetic Nephropathy in Nondiabetic Mice. Diabetes 2014, 63, 291-299. [CrossRef] [PubMed]

110. Mclellan, A.C.; Thornalley, P.J.; Benn, J.; Sonksen, P.H. Glyoxalase System in Clinical Diabetes Mellitus and Correlation with Diabetic Complications. Clin. Sci. 1994, 87, 21-29. [CrossRef] [PubMed]

111. Thornalley, P.J.; Hooper, N.I.; Jennings, P.E.; Florkowski, C.M.; Jones, A.F.; Lunec, J.; Barnett, A.H. The Human Red Blood Cell Glyoxalase System in Diabetes Mellitus. Diabetes Res. Clin. Pract. 1989, 7, 115-120. [CrossRef]

112. Rabbani, N.; Thornalley, P.J. Glyoxalase in Diabetes, Obesity and Related Disorders. Semin. Cell. Dev. Biol. 2011, 22, 309-317. [CrossRef] [PubMed]

113. Staniszewska, M.M.; Nagaraj, R.H. Upregulation of Glyoxalase I Fails to Normalize Methylglyoxal Levels: A Possible Mechanism for Biochemical Changes in Diabetic Mouse Lenses. Mol. Cell. Biochem. 2006, 288, 29-36. [CrossRef] [PubMed]

114. Metzger, R.P.; Sauerheber, R.D.; Lyons, S.A.; Westall, J.R. The Effect of Streptozotocin Diabetes on the Levels of Glycolate and Lactate Excreted in Rat Urine. Arch. Biochem. Biophys. 1975, 169, 555-559. [CrossRef]

115. Vander Jagt, D.L.; Hassebrook, R.K.; Hunsaker, L.A.; Brown, W.M.; Royer, R.E. Metabolism of the 2-Oxoaldehyde Methylglyoxal by Aldose Reductase and by Glyoxalase-I: Roles for Glutathione in Both Enzymes and Implications for Diabetic Complications. Chem. Biol. Interact. 2001, 130-132, 549-562. [CrossRef]

116. Vander Jagt, D.L.; Hunsaker, L.A.; Young, B.S.; Brown, W.M. Aldo-Keto Reductase-Catalyzed Detoxication of Endogenous Aldehydes Associated with Diabetic Complications. In Aldo-Keto Reductases and Toxicant Metabolism; American Chemical Society: Washington, WA, USA, 2003; Volume 865, pp. 23-35.

117. Kato, H.; Van Chuyen, N.; Shinoda, T.; Sekiya, F.; Hayase, F. Metabolism of 3-Deoxyglucosone, An Intermediate Compound in the Maillard Reaction, Administered Orally or Intravenously to Rats. Biochim. Biophys. Acta 1990, 1035, 71-76. [CrossRef]

118. Suzuki, K.; Koh, Y.H.; Mizuno, H.; Hamaoka, R.; Taniguchi, N. Overexpression of Aldehyde Reductase Protects PC12 Cells From the Cytotoxicity of Methylglyoxal or 3-Deoxyglucosone. J. Biochem. 1998, 123, 353-357. [CrossRef] [PubMed]

119. Baba, S.P.; Barski, O.A.; Ahmed, Y.; O'toole, T.E.; Conklin, D.J.; Bhatnagar, A.; Srivastava, S. Reductive Metabolism of Age Precursors: A Metabolic Route for Preventing Age Accumulation in Cardiovascular Tissue. Diabetes 2009, 58, 2486-2497. [CrossRef] [PubMed]

120. Vander Jagt, D.L. Methylglyoxal, Diabetes Mellitus and Diabetic Complications. Drug Metab. Drug Interact. 2008, 23, 93-124.

121. Degen, J.; Beyer, H.; Heymann, B.; Hellwig, M.; Henle, T. Dietary Influence on Urinary Excretion of 3-Deoxyglucosone and Its Metabolite 3-Deoxyfructose. J. Agric. Food Chem. 2014, 62, 2449-2456. [CrossRef] [PubMed]

122. Fujii, E.; Iwase, H.; Ishii-Karakasa, I.; Yajima, Y.; Hotta, K. The Presence of 2-Keto-3-Deoxygluconic Acid and Oxoaldehyde Dehydrogenase Activity in Human Erythrocytes. Biochem. Biophys. Res. Commun. 1995, 210, 852-857. [CrossRef] [PubMed] 
123. Collard, F.; Vertommen, D.; Fortpied, J.; Duester, G.; Van Schaftingen, E. Identification of 3-Deoxyglucosone Dehydrogenase as Aldehyde Dehydrogenase 1a1 (Retinaldehyde Dehydrogenase 1). Biochimie 2007, 89, 369-373. [CrossRef] [PubMed]

124. Nikiforova, V.J.; Giesbertz, P.; Wiemer, J.; Bethan, B.; Looser, R.; Liebenberg, V.; Ruiz Noppinger, P.; Daniel, H.; Rein, D. Glyoxylate, A New Marker Metabolite of Type 2 Diabetes. J. Diabetes Res. 2014, 2014, 685204. [CrossRef] [PubMed]

125. Kiefer, F.W.; Vernochet, C.; O’brien, P.; Spoerl, S.; Brown, J.D.; Nallamshetty, S.; Zeyda, M.; Stulnig, T.M.; Cohen, D.E.; Kahn, C.R.; et al. Retinaldehyde Dehydrogenase 1 Regulates a Thermogenic Program in White Adipose Tissue. Nat. Med. 2012, 18, 918-925. [CrossRef] [PubMed]

126. Veiga Da-Cunha, M.; Jacquemin, P.; Delpierre, G.; Godfraind, C.; Theate, I.; Vertommen, D.; Clotman, F.; Lemaigre, F.; Devuyst, O.; Van Schaftingen, E. Increased Protein Glycation in Fructosamine 3-Kinase-Deficient Mice. Biochem. J. 2006, 399, 257-264. [CrossRef] [PubMed]

127. Uchiki, T.; Weikel, K.A.; Jiao, W.; Shang, F.; Caceres, A.; Pawlak, D.; Handa, J.T.; Brownlee, M.; Nagaraj, R.; Taylor, A. Glycation-Altered Proteolysis as A Pathobiologic Mechanism That Links Dietary Glycemic Index, Aging, and Age-Related Disease (in Nondiabetics). Aging Cell 2012, 11, 1-13. [CrossRef] [PubMed]

128. Knecht, R.; Leber, R.; Hasslacher, C. Degradation of Glomerular Basement Membrane in Diabetes. I. Susceptibility of Diabetic and Nondiabetic Basement Membrane to Proteolytic Degradation of Isolated Glomeruli. Res. Exp. Med. 1987, 187, 323-328. [CrossRef]

129. Leber, R.; Knecht, R.; Hasslacher, C. Degradation of Glomerular Basement Membrane in Diabetes. II. Proteolytic Activity of Diabetic and Nondiabetic Glomeruli. Res. Exp. Med. 1987, 187, 347-352. [CrossRef]

130. Grimm, S.; Horlacher, M.; Catalgol, B.; Hoehn, A.; Reinheckel, T.; Grune, T. Cathepsins D and L Reduce the Toxicity of Advanced Glycation End Products. Free Radic. Biol. Med. 2012, 52, 1011-1023. [CrossRef] [PubMed]

131. Ahmed, N.; Babaei-Jadidi, R.; Howell, S.K.; Beisswenger, P.J.; Thornalley, P.J. Degradation Products of Proteins Damaged by Glycation, Oxidation and Nitration in Clinical Type 1 Diabetes. Diabetologia 2005, 48, 1590-1603. [CrossRef] [PubMed]

132. Gougeon, R.; Morais, J.A.; Chevalier, S.; Pereira, S.; Lamarche, M.; Marliss, E.B. Determinants of Whole-Body Protein Metabolism in Subjects with and without Type 2 Diabetes. Diabetes Care 2008, 31, 128-133. [CrossRef] [PubMed]

133. Hebert, S.L.; Nair, K.S. Protein and Energy Metabolism in Type 1 Diabetes. Clin. Nutr. 2010, $29,13-17$. [CrossRef] [PubMed]

134. Inzucchi, S.E.; Bergenstal, R.M.; Buse, J.B.; Diamant, M.; Ferrannini, E.; Nauck, M.; Peters, A.L.; Tsapas, A.; Wender, R.; Matthews, D.R. Management of Hyperglycaemia in Type 2 Diabetes: A Patient-Centered Approach. Position Statement of the American Diabetes Association (ADA) and the European Association for the Study of Diabetes (EASD). Diabetologia 2012, 55, 1577-1596. [CrossRef] [PubMed]

135. Borg, D.J.; Forbes, J.M. Targeting Advanced Glycation with Pharmaceutical Agents: Where Are We Now? Glycoconj. J. 2016, 33, 653-670. [CrossRef] [PubMed]

136. Brownlee, M.; Vlassara, H.; Kooney, A.; Ulrich, P.; Cerami, A. Aminoguanidine Prevents Diabetes-Induced Arterial Wall Protein Cross-Linking. Science 1986, 232, 1629-1632. [CrossRef] [PubMed]

137. Dhar, A.; Dhar, I.; Desai, K.M.; Wu, L. Methylglyoxal Scavengers Attenuate Endothelial Dysfunction Induced by Methylglyoxal and High Concentrations of Glucose. Br. J. Pharmacol. 2010, 161, 1843-1856. [CrossRef] [PubMed]

138. Nyengaard, J.R.; Chang, K.; Berhorst, S.; Reiser, K.M.; Williamson, J.R.; Tilton, R.G. Discordant Effects of Guanidines on Renal Structure and Function and on Regional Vascular Dysfunction and Collagen Changes in Diabetic Rats. Diabetes 1997, 46, 94-106. [CrossRef] [PubMed]

139. Soulis, T.; Cooper, M.E.; Sastra, S.; Thallas, V.; Panagiotopoulos, S.; Bjerrum, O.J.; Jerums, G. Relative Contributions of Advanced Glycation and Nitric Oxide Synthase Inhibition to Aminoguanidine-Mediated Renoprotection in Diabetic Rats. Diabetologia 1997, 40, 1141-1151. [CrossRef] [PubMed]

140. Degenhardt, T.P.; Fu, M.X.; Voss, E.; Reiff, K.; Neidlein, R.; Strein, K.; Thorpe, S.R.; Baynes, J.W.; Reiter, R. Aminoguanidine Inhibits Albuminuria, But Not the Formation of Advanced Glycation End-Products in Skin Collagen of Diabetic Rats. Diabetes Res. Clin. Pract. 1999, 43, 81-89. [CrossRef] 
141. Hammes, H.P.; Martin, S.; Federlin, K.; Geisen, K.; Brownlee, M. Aminoguanidine Treatment Inhibits the Development of Experimental Diabetic Retinopathy. Proc. Natl. Acad. Sci. USA 1991, 88, 11555-11558. [CrossRef] [PubMed]

142. Bolton, W.K.; Cattran, D.C.; Williams, M.E.; Adler, S.G.; Appel, G.B.; Cartwright, K.; Foiles, P.G.; Freedman, B.I.; Raskin, P.; Ratner, R.E.; et al. Randomized Trial of An Inhibitor of Formation of Advanced Glycation End Products in Diabetic Nephropathy. Am. J. Nephrol. 2004, 24, 32-40. [CrossRef] [PubMed]

143. Freedman, B.I.; Wuerth, J.P.; Cartwright, K.; Bain, R.P.; Dippe, S.; Hershon, K.; Mooradian, A.D.; Spinowitz, B.S. Design and Baseline Characteristics for the Aminoguanidine Clinical Trial in Overt Type 2 Diabetic Nephropathy (ACTION II). Control. Clin. Trials 1999, 20, 493-510. [CrossRef]

144. Corbett, J.A.; Tilton, R.G.; Chang, K.; Hasan, K.S.; Ido, Y.; Wang, J.L.; Sweetland, M.A.; Lancaster, J.R., Jr.; Williamson, J.R.; Mcdaniel, M.L. Aminoguanidine, A Novel Inhibitor of Nitric Oxide Formation, Prevents Diabetic Vascular Dysfunction. Diabetes 1992, 41, 552-556. [CrossRef] [PubMed]

145. Bowman, M.A.; Simell, O.G.; Peck, A.B.; Cornelius, J.; Luchetta, R.; Look, Z.; Maclaren, N.K.; Atkinson, M.A. Pharmacokinetics of Aminoguanidine Administration and Effects on the Diabetes Frequency in Nonobese Diabetic Mice. J. Pharmacol. Exp. Ther. 1996, 279, 790-794. [PubMed]

146. Voziyan, P.A.; Metz, T.O.; Baynes, J.W.; Hudson, B.G. A Post-Amadori Inhibitor Pyridoxamine Also Inhibits Chemical Modification of Proteins by Scavenging Carbonyl Intermediates of Carbohydrate and Lipid Degradation. J. Biol. Chem. 2002, 277, 3397-3403. [CrossRef] [PubMed]

147. Voziyan, P.A.; Khalifah, R.G.; Thibaudeau, C.; Yildiz, A.; Jacob, J.; Serianni, A.S.; Hudson, B.G. Modification of Proteins in Vitro by Physiological Levels of Glucose: Pyridoxamine Inhibits Conversion of Amadori Intermediate to Advanced Glycation End-Products Through Binding of Redox Metal Ions. J. Biol. Chem. 2003, 278, 46616-46624. [CrossRef] [PubMed]

148. Nagai, R.; Murray, D.B.; Metz, T.O.; Baynes, J.W. Chelation: A Fundamental Mechanism of Action of AGE Inhibitors, AGE Breakers, and Other Inhibitors of Diabetes Complications. Diabetes 2012, 61, 549-559. [CrossRef] [PubMed]

149. Tanimoto, M.; Gohda, T.; Kaneko, S.; Hagiwara, S.; Murakoshi, M.; Aoki, T.; Yamada, K.; Ito, T.; Matsumoto, M.; Horikoshi, S.; et al. Effect of Pyridoxamine (K-163), An Inhibitor of Advanced Glycation End Products, on Type 2 Diabetic Nephropathy in KK-A(y)/Ta Mice. Metab. Clin. Exp. 2007, 56, 160-167. [CrossRef] [PubMed]

150. Degenhardt, T.P.; Alderson, N.L.; Arrington, D.D.; Beattie, R.J.; Basgen, J.M.; Steffes, M.W.; Thorpe, S.R.; Baynes, J.W. Pyridoxamine Inhibits Early Renal Disease and Dyslipidemia in the Streptozotocin-Diabetic Rat. Kidney Int. 2002, 61, 939-950. [CrossRef] [PubMed]

151. Stitt, A.; Gardiner, T.A.; Alderson, N.L.; Canning, P.; Frizzell, N.; Duffy, N.; Boyle, C.; Januszewski, A.S.; Chachich, M.; Baynes, J.W.; et al. The AGE Inhibitor Pyridoxamine Inhibits Development of Retinopathy in Experimental Diabetes. Diabetes 2002, 51, 2826-2832. [CrossRef] [PubMed]

152. Williams, M.E.; Bolton, W.K.; Khalifah, R.G.; Degenhardt, T.P.; Schotzinger, R.J.; Mcgill, J.B. Effects of Pyridoxamine in Combined Phase 2 Studies of Patients with Type 1 and Type 2 Diabetes and Overt Nephropathy. Am. J. Nephrol. 2007, 27, 605-614. [CrossRef] [PubMed]

153. Lewis, E.J.; Greene, T.; Spitalewiz, S.; Blumenthal, S.; Berl, T.; Hunsicker, L.G.; Pohl, M.A.; Rohde, R.D.; Raz, I.; Yerushalmy, Y.; et al. Pyridorin in Type 2 Diabetic Nephropathy. J. Am. Soc. Nephrol. 2012, 23, 131-136. [CrossRef] [PubMed]

154. Adrover, M.; Vilanova, B.; Frau, J.; Munoz, F.; Donoso, J. A Comparative Study of the Chemical Reactivity of Pyridoxamine, Ac-Phe-Lys and Ac-Cys with Various Glycating Carbonyl Compounds. Amino Acids 2009, 36, 437-448. [CrossRef] [PubMed]

155. Nagaraj, R.H.; Sarkar, P.; Mally, A.; Biemel, K.M.; Lederer, M.O.; Padayatti, P.S. Effect of Pyridoxamine on Chemical Modification of Proteins by Carbonyls in Diabetic Rats: Characterization of A Major Product From the Reaction of Pyridoxamine and Methylglyoxal. Arch. Biochem. Biophys. 2002, 402, 110-119. [CrossRef]

156. Kinsky, O.R.; Hargraves, T.L.; Anumol, T.; Jacobsen, N.E.; Dai, J.; Snyder, S.A.; Monks, T.J.; Lau, S.S. Metformin Scavenges Methylglyoxal to Form A Novel Imidazolinone Metabolite in Humans. Chem. Res. Toxicol. 2016, 29, 227-234. [CrossRef] [PubMed]

157. Brings, S.; Fleming, T.; De Buhr, S.; Beijer, B.; Lindner, T.; Wischnjow, A.; Kender, Z.; Peters, V.; Kopf, S.; Haberkorn, U.; et al. A Scavenger Peptide Prevents Methylglyoxal Induced Pain in Mice. Biochim. Biophys. Acta 2016, 1863, 654-662. [CrossRef] [PubMed] 
158. Beisswenger, P.J.; Howell, S.K.; Touchette, A.D.; Lal, S.; Szwergold, B.S. Metformin Reduces Systemic Methylglyoxal Levels in Type 2 Diabetes. Diabetes 1999, 48, 198-202. [CrossRef] [PubMed]

159. Battah, S.; Ahmed, N.; Thornalley, P.J. Kinetics and Mechanism of the Reaction of Metformin with Methylglyoxal. Int. Congr. Ser. 2002, 1245, 355-356. [CrossRef]

160. Kender, Z.; Fleming, T.; Kopf, S.; Torzsa, P.; Grolmusz, V.; Herzig, S.; Schleicher, E.; Racz, K.; Reismann, P.; Nawroth, P.P. Effect of Metformin on Methylglyoxal Metabolism in Patients with Type 2 Diabetes. Exp. Clin. Endocrinol. Diabetes 2014, 122, 316-319. [CrossRef] [PubMed]

161. Vasan, S.; Zhang, X.; Zhang, X.; Kapurniotu, A.; Bernhagen, J.; Teichberg, S.; Basgen, J.; Wagle, D.; Shih, D.; Terlecky, I.; et al. An Agent Cleaving Glucose-Derived Protein Crosslinks in Vitro and in Vivo. Nature 1996, 382, 275-278. [CrossRef] [PubMed]

162. Wolffenbuttel, B.H.; Boulanger, C.M.; Crijns, F.R.; Huijberts, M.S.; Poitevin, P.; Swennen, G.N.; Vasan, S.; Egan, J.J.; Ulrich, P.; Cerami, A.; et al. Breakers of Advanced Glycation End Products Restore Large Artery Properties in Experimental Diabetes. Proc. Natl. Acad. Sci. USA 1998, 95, 4630-4634. [CrossRef] [PubMed]

163. Yang, S.; Litchfield, J.E.; Baynes, J.W. AGE-Breakers Cleave Model Compounds, But Do Not Break Maillard Crosslinks in Skin and Tail Collagen From Diabetic Rats. Arch. Biochem. Biophys. 2003, 412, 42-46. [CrossRef]

164. Dhar, A.; Desai, K.M.; Wu, L. Alagebrium Attenuates Acute Methylglyoxal-Induced Glucose Intolerance in Sprague-Dawley Rats. Br. J. Pharmacol. 2010, 159, 166-175. [CrossRef] [PubMed]

165. Kim, T.; Spiegel, D.A. The Unique Reactivity of N-Phenacyl-Derived Thiazolium Salts Toward $\alpha$-Dicarbonyl Compounds. Rejuvenation Res. 2013, 16, 43-50. [CrossRef] [PubMed]

166. Thallas-Bonke, V.; Lindschau, C.; Rizkalla, B.; Bach, L.A.; Boner, G.; Meier, M.; Haller, H.; Cooper, M.E.; Forbes, J.M. Attenuation of Extracellular Matrix Accumulation in Diabetic Nephropathy by the Advanced Glycation End Product Cross-Link Breaker ALT-711 Via A Protein Kinase C- $\alpha$-Dependent Pathway. Diabetes 2004, 53, 2921-2930. [CrossRef] [PubMed]

167. Xue, M.; Rabbani, N.; Momiji, H.; Imbasi, P.; Anwar, M.M.; Kitteringham, N.; Park, B.K.; Souma, T.; Moriguchi, T.; Yamamoto, M.; et al. Transcriptional Control of Glyoxalase 1 by Nrf2 Provides A Stress-Responsive Defence Against Dicarbonyl Glycation. Biochem. J. 2012, 443, 213-222. [CrossRef] [PubMed]

168. Xue, M.; Weickert, M.O.; Qureshi, S.; Kandala, N.B.; Anwar, A.; Waldron, M.; Shafie, A.; Messenger, D.; Fowler, M.; Jenkins, G.; et al. Improved Glycemic Control and Vascular Function in Overweight and Obese Subjects by Glyoxalase 1 Inducer Formulation. Diabetes 2016, 65, 2282-2294. [CrossRef] [PubMed]

169. Zheng, Y.; Li, X.K.; Wang, Y.; Cai, L. The Role of Zinc, Copper and Iron in the Pathogenesis of Diabetes and Diabetic Complications: Therapeutic Effects by Chelators. Hemoglobin 2008, 32, 135-145. [CrossRef] [PubMed]

170. Wells-Knecht, M.C.; Thorpe, S.R.; Baynes, J.W. Pathways of Formation of Glycoxidation Products During Glycation of Collagen. Biochemistry 1995, 34, 15134-15141. [CrossRef] [PubMed]

171. Nagai, R.; Nagai, M.; Shimasaki, S.; Baynes, J.W.; Fujiwara, Y. Citric Acid Inhibits Development of Cataracts, Proteinuria and Ketosis in Streptozotocin (Type 1) Diabetic Rats. Biochem. Biophys. Res. Commun. 2010, 393, 118-122. [CrossRef] [PubMed]

172. Cameron, N.E.; Cotter, M.A. Neurovascular Dysfunction in Diabetic Rats. Potential Contribution of Autoxidation and Free Radicals Examined Using Transition Metal Chelating Agents. J. Clin. Investig. 1995, 96, 1159-1163. [CrossRef] [PubMed]

173. Cameron, N.E.; Cotter, M.A. Effects of An Extracellular Metal Chelator on Neurovascular Function in Diabetic Rats. Diabetologia 2001, 44, 621-628. [CrossRef] [PubMed]

174. Lamas, G.A.; Goertz, C.; Boineau, R.; Mark, D.B.; Rozema, T.; Nahin, R.L.; Lindblad, L.; Lewis, E.F.; Drisko, J.; Lee, K.L.; et al. Effect of Disodium EDTA Chelation Regimen on Cardiovascular Events in Patients with Previous Myocardial Infarction: The Tact Randomized Trial. JAMA 2013, 309, 1241-1250. [CrossRef] [PubMed]

175. Escolar, E.; Lamas, G.A.; Mark, D.B.; Boineau, R.; Goertz, C.; Rosenberg, Y.; Nahin, R.L.; Ouyang, P.; Rozema, T.; Magaziner, A.; et al. The Effect of An EDTA-Based Chelation Regimen on Patients with Diabetes Mellitus and Prior Myocardial Infarction in the Trial to Assess Chelation Therapy (TACT). Circ. Cardiovasc. Qual. Outcomes 2014, 7, 15-24. [CrossRef] [PubMed] 
176. Cooper, G.J.; Young, A.A.; Gamble, G.D.; Occleshaw, C.J.; Dissanayake, A.M.; Cowan, B.R.; Brunton, D.H.; Baker, J.R.; Phillips, A.R.; Frampton, C.M.; et al. A Copper(II)-Selective Chelator Ameliorates Left-Ventricular Hypertrophy in Type 2 Diabetic Patients: A Randomised Placebo-Controlled Study. Diabetologia 2009, 52, 715-722. [CrossRef] [PubMed]

177. Mahmood, I. Application of Allometric Principles for the Prediction of Pharmacokinetics in Human and Veterinary Drug Development. Adv. Drug Deliv. Rev. 2007, 59, 1177-1192. [CrossRef] [PubMed]

178. Gineyts, E.; Cloos, P.A.; Borel, O.; Grimaud, L.; Delmas, P.D.; Garnero, P. Racemization and Isomerization of Type I Collagen C-Telopeptides in Human Bone and Soft Tissues: Assessment of Tissue Turnover. Biochem. J. 2000, 345, 481-485. [CrossRef] [PubMed]

179. Szwergold, B.S. Fructosamine-6-Phosphates Are Deglycated by Phosphorylation to Fructosamine-3,6Bisphosphates Catalyzed by Fructosamine-3-Kinase (FN3K) and/Or Fructosamine-3-Kinase-Related-Protein (FN3KRP). Med. Hypotheses 2007, 68, 37-45. [CrossRef] [PubMed]

(C) 2017 by the authors. Licensee MDPI, Basel, Switzerland. This article is an open access article distributed under the terms and conditions of the Creative Commons Attribution (CC BY) license (http://creativecommons.org/licenses/by/4.0/). 